\title{
Evaluation of European air quality modelled by CAMx including the volatility basis set scheme
}

\author{
Giancarlo Ciarelli $^{1}$, Sebnem Aksoyoglu ${ }^{1}$, Monica Crippa ${ }^{1, a}$, Jose-Luis Jimenez ${ }^{2,3}$, Eriko Nemitz ${ }^{4}$, Karine Sellegri ${ }^{5}$, \\ Mikko Äijälä ${ }^{6}$, Samara Carbone ${ }^{7, b}$, Claudia Mohr ${ }^{8}$, Colin O'Dowd ${ }^{9}$, Laurent Poulain ${ }^{10}$, Urs Baltensperger ${ }^{1}$, and \\ André S. H. Prévôt ${ }^{1}$ \\ ${ }^{1}$ Paul Scherrer Institute, Laboratory of Atmospheric Chemistry, 5232 Villigen PSI, Switzerland \\ ${ }^{2}$ Cooperative Institute for Research in Environmental Sciences, University of Colorado, Boulder, CO 80309, USA \\ ${ }^{3}$ Department of Chemistry and Biochemistry, University of Colorado, Boulder, CO 80309, USA \\ ${ }^{4}$ Centre for Ecology and Hydrology, Bush Estate, Penicuik, Midlothian, EH26 0QB, UK \\ ${ }^{5}$ Laboratoire de Météorologie Physique CNRS UMR6016, Observatoire de Physique du Globe de Clermont-Ferrand, \\ Université Blaise Pascal, 63171 Aubière, France \\ ${ }^{6}$ University of Helsinki, Department of Physics, Helsinki, Finland \\ ${ }^{7}$ Atmospheric Composition Research, Finnish Meteorological Institute, P.O. Box 503, 00101 Helsinki, Finland \\ ${ }^{8}$ Karlsruhe Institute of Technology, Institute of Meteorology and Climate Research, Germany \\ ${ }^{9}$ School of Physics and Centre for Climate \& Air Pollution Studies, Ryan Institute, National University of Ireland Galway, \\ University Road, Galway, Ireland \\ ${ }^{10}$ Leibniz-Institute for Tropospheric Research (TROPOS), Permoserstr. 15, 04318 Leipzig, Germany \\ ${ }^{a}$ now at: European Commission, Joint Research Centre (JRC), Institute for Environment and Sustainability (IES), Via Fermi, \\ 2749, 21027 Ispra, Italy \\ ${ }^{\text {b }}$ now at: Institute of Physics, University of São Paulo, Rua do Matão Travessa R, 187, 05508-090 São Paulo, S.P., Brazil
}

Correspondence to: S. Aksoyoglu (sebnem.aksoyoglu@psi.ch)

Received: 1 September 2015 - Published in Atmos. Chem. Phys. Discuss.: 17 December 2015

Revised: 27 May 2016 - Accepted: 19 July 2016 - Published: 16 August 2016

\begin{abstract}
Four periods of EMEP (European Monitoring and Evaluation Programme) intensive measurement campaigns (June 2006, January 2007, September-October 2008 and February-March 2009) were modelled using the regional air quality model CAMx with VBS (volatility basis set) approach for the first time in Europe within the framework of the EURODELTA-III model intercomparison exercise. More detailed analysis and sensitivity tests were performed for the period of February-March 2009 and June 2006 to investigate the uncertainties in emissions as well as to improve the modelling of organic aerosol (OA). Model performance for selected gas phase species and $\mathrm{PM}_{2.5}$ was evaluated using the European air quality database AirBase. Sulfur dioxide $\left(\mathrm{SO}_{2}\right)$ and ozone $\left(\mathrm{O}_{3}\right)$ were found to be overestimated for all the four periods, with $\mathrm{O}_{3}$ having the largest mean bias during June 2006 and January-February 2007 periods ( 8.9 pbb and $12.3 \mathrm{ppb}$ mean biases respectively). In contrast, nitro-
\end{abstract}

gen dioxide $\left(\mathrm{NO}_{2}\right)$ and carbon monoxide $(\mathrm{CO})$ were found to be underestimated for all the four periods. CAMx reproduced both total concentrations and monthly variations of $\mathrm{PM}_{2.5}$ for all the four periods with average biases ranging from -2.1 to $1.0 \mu \mathrm{g} \mathrm{m}^{-3}$. Comparisons with AMS (aerosol mass spectrometer) measurements at different sites in $\mathrm{Eu}-$ rope during February-March 2009 showed that in general the model overpredicts the inorganic aerosol fraction and underpredicts the organic one, such that the good agreement for $\mathrm{PM}_{2.5}$ is partly due to compensation of errors. The effect of the choice of VBS scheme on OA was investigated as well. Two sensitivity tests with volatility distributions based on previous chamber and ambient measurements data were performed. For February-March 2009 the chamber case reduced the total OA concentrations by about $42 \%$ on average. In contrast, a test based on ambient measurement data increased OA concentrations by about $42 \%$ for the same 
period bringing model and observations into better agreement. Comparison with the AMS data at the rural Swiss site Payerne in June 2006 shows no significant improvement in modelled OA concentration. Further sensitivity tests with increased biogenic and anthropogenic emissions suggest that OA in Payerne was affected by changes in emissions from residential heating during the February-March 2009 whereas it was more sensitive to biogenic precursors in June 2006.

\section{Introduction}

Air pollution is known to cause damage to human health, vegetation and ecosystems. It is one of the main environmental causes of premature death. Only in Europe, more than 400000 premature deaths were estimated in 2012, with $\mathrm{PM}_{2.5}$ (particles less than $2.5 \mu \mathrm{m}$ in aerodynamic diameter) having the highest relative risk for health damage (WHO, 2014). Air quality models help to understand the processes taking place between emission sources and pollutant concentrations at receptor sites. They are very useful for defining control strategies for future legislation. In spite of large improvements in recent years, chemical transport models (CTMs) still have some uncertainties (Solazzo et al., 2012). Various air quality model intercomparison exercises were successfully carried out over the last decades to determine uncertainties in chemical and physical processes governing particulate matter and its precursors (Solazzo et al., 2012; Bessagnet et al., 2014). However, a large variability in particulate matter concentrations was found between different models, indicating process parameterization as one of the main reasons for such discrepancies. Moreover, recent studies based on AMS (aerosol mass spectrometer) measurements at different sites in Europe revealed that the organic fraction dominates the non-refractory $\mathrm{PM}_{1}$ composition (Crippa et al., 2014). Organic aerosol (OA) can be found in the atmosphere from direct emission by various sources, such as fossil fuel combustion by road vehicle engines or residential wood combustion. Direct emissions of OA are typically referred to as primary organic aerosol (POA) whereas gas-to-particle conversion is referred to as secondary organic aerosol (SOA). Formation mechanisms of SOAs are not very well known yet and their representation in CTMs is still challenging (Hallquist et al., 2009; Fountoukis et al., 2011; Bergström et al., 2012; Li et al., 2013; Langmann et al., 2014; Tsigaridis et al., 2014). In one of our recent aerosol modelling studies we compared model $\mathrm{PM}_{2.5}$ prediction with $\mathrm{PM}_{1}$ AMS measurements for different sites (Payerne and Zürich) and periods (summer and winter) in Switzerland. We found that particulate matter was generally well reproduced by the model with the SOA fraction being underpredicted and POA overpredicted (Aksoyoglu et al., 2011). Traditional CTMs treat POA as nonvolatile. Some studies, however, have revealed the semivolatile nature of POA, through its dynamic equilibrium of organic aerosol with its gas phase, and the importance of semivolatile (SVOC) and intermediate volatility (IVOC) organic compounds as SOA precursors (Donahue et al., 2006; Robinson et al., 2007; Cappa and Jimenez, 2010). To describe the absorptive partitioning and ongoing oxidation of the atmospheric material, a volatility basis set (VBS) where organic species are organized into surrogates according to their volatility was developed (Donahue et al., 2011, 2012a, b). Air quality models updated with the VBS scheme started being used (Lane et al., 2008; Murphy and Pandis, 2009; Hodzic et al., 2010; Fountoukis et al., 2011, 2014; Bergström et al., 2012; Murphy et al., 2012; Jo et al., 2013; Zhang et al., 2013; Athanasopoulou et al., 2013). Bergström et al. (2012) reported an EMEP model study over Europe for the 2002-2007 period using different assumptions regarding partitioning and aging processes. They could not reproduce the measured OA levels in winter, suggesting that residential wood combustion inventories might be underestimated in different parts of Europe. Fountoukis et al. (2014) applied the PMCAMx model to simulate EUCAARI (Kulmala et al., 2009, 2011) and EMEP (Tørseth et al., 2012) campaigns in Europe. They could reproduce most of $\mathrm{PM}_{1}$ daily average OA observations within a factor of 2, with the FebruaryMarch 2009 period having the largest discrepancies. Zhang et al. (2013) deployed the CHIMERE model with the VBS framework during the MEGAPOLI summer campaign in the Greater Paris region for July 2009. They found a considerable improvement in predicted SOA concentrations which might be even overestimated depending on the emission inventory used. In our study, we applied the regional air quality model CAMx with the VBS scheme for the first time in Europe within the framework of EURODELTA-III (EDIII) model intercomparison exercise. In addition to the base case configuration used in the exercise, more sensitivity tests with the VBS scheme for winter and summer episodes were performed together with a general evaluation of the four EMEP field measurement campaigns.

\section{Method}

\subsection{The EURODELTA-III exercise}

The EDIII framework is a European model intercomparison exercise between several modelling teams sharing both efforts and technical knowledge in order to reduce model uncertainties and to improve understanding of the performances. It contributes to the scientific work of the United Nations Economic Commission for Europe (UNECE) Task Force on Measurement and Modelling (TFMM) within the Convention on Long-range Transboundary Air Pollution (CLRTAP). In the first phase of the EDIII exercise, four periods of the EMEP field measurement campaigns were chosen in order to evaluate the model results:

- 1 June-30 June 2006 
- 8 January-4 February 2007

- 17 September-15 October 2008

- 25 February-26 March 2009.

Multiple models were applied on a common domain and driven with the same input data provided by the National Institute for Industrial Environment and Risks (INERIS). However, for some models, different meteorology, boundary conditions and emissions data such as biogenic emissions were used (Bessagnet et al., 2014).

\subsection{Modelling method}

\subsubsection{CAMx}

The Comprehensive Air quality Model with extensions, CAMx-VBS (CAMx5.41_VBS, kindly provided by ENVIRON before its public release), was used in this study. The model domain consisted of one grid with a horizontal resolution of $0.25^{\circ} \times 0.25^{\circ}$. The latitude and longitude grids extended from $25.125^{\circ} \mathrm{W}$ to $45.125^{\circ} \mathrm{E}$ and 29.875 to $70.125^{\circ} \mathrm{N}$, resulting in $281 \times 161$ grid cells covering the whole of Europe. Hourly four-dimensional meteorological fields for wind speed and direction, pressure, temperature, specific humidity, cloud cover and rain required by CAMx simulations were calculated from ECMWF IFS (Integrated Forecast System) data at $0.2^{\circ}$ resolution. Vertical diffusivity coefficients were estimated following the $\mathrm{Kz}$ approach of O'Brien (1970) using planetary boundary layer depth profiles as available in IFS data. CAMx simulations used 33 terrain-following $\sigma$-levels up to about $8000 \mathrm{~m}$ above ground level, as in the original IFS data. The lowest layer was about $20 \mathrm{~m}$ thick. MACC (Monitoring Atmospheric Composition and Climate) reanalysis data were used to initialize initial and the boundary condition fields (Benedetti et al., 2009; Inness et al., 2013). Elemental carbon, organic aerosol, dust and sulfate were used to model aerosol species at the boundaries of the domain. One half of the OA was assumed to be SOA and the other half POA, as recommended in the EDIII exercise. Photolysis rate inputs were calculated using the Tropospheric Ultraviolet and Visible (TUV) radiative transfer and photolysis model (https://www2.acom.ucar.edu/modeling/ tropospheric-ultraviolet-and-visible-tuv-radiation-model).

The required ozone column densities to determine the spatial and temporal variation of the photolysis rates were extracted from TOMS data (NASA/GSFC, 2005). Removal processes as dry and wet deposition were simulated using the Zhang resistance model (Zhang et al., 2003) and a scavenging model approach for both gases and aerosols (Environ, 2011), respectively. For the gas phase chemistry the carbon bond (CB05) mechanism (Yarwood et al., 2005) with 156 reactions and up to 89 species was used. Partitioning of inorganic aerosols (sulfate, nitrate, ammonium, sodium and chloride) was performed using the ISORROPIA thermodynamic model (Nenes et al., 1998). Aqueous sulfate and nitrate formation in cloud water was simulated as well, using the RADM aqueous chemistry algorithm (Chang et al., 1987).

\subsubsection{Emissions}

\section{Anthropogenic emissions}

Annual total gridded anthropogenic emissions were prepared and provided by INERIS for the EDIII exercise, which is based on a merging process of databases from different sources, i.e. TNO-MACC (Kuenen et al., 2011), EMEP (Vestreng et al., 2007) and GAINS (The Greenhouse Gas and Air Pollution Interactions and Synergies). For specific countries where TNO-MACC emissions were missing (Iceland, Liechtenstein, Malta and Asian countries), the EMEP $0.5^{\circ} \times 0.5^{\circ}$ emissions were used and re-gridded using adequate proxies such as "artificial land-use" and EPER (European Pollutant Emission Register) data (http://www.eea. europa.eu/) for industries. Total primary particle emissions were made available by EMEP in two different size ranges: below $2.5 \mu \mathrm{m}$ (fine) and between $2.5 \mu \mathrm{m}$ and $10 \mu \mathrm{m}$ (coarse). Total emissions were later split to estimate the amount of elemental carbon and organic matter for each of the 10 SNAP codes (Selected Nomenclature for Air Pollution) and country. The final emission inventory thus compiled consisted of six gas species, namely methane, carbon monoxide, ammonia, sulfur oxides, non-methane volatile organic compounds and nitrogen oxides, and six categories of particulate matter classes: fine elemental carbon (EC2.5), coarse elemental carbon (EC10), fine POA, coarse POA, fine other primary particulate material (non-carbonaceous) and coarse other primary particulate material (non-carbonaceous). $\mathrm{PM}_{2.5}$ and $\mathrm{PM}_{10}$ emissions were provided by EMEP and they were split to elemental carbon and organic matter using the fractions given by IIASA (International Institute for Applied Systems Analysis) for each source and country. Total non-methane volatile organic compounds were split for the CB05 mechanism using the recommendations of Passant (2002). Hourly, weekly and monthly time profiles were applied to total annual anthropogenic emissions.

\section{Biogenic emissions}

Biogenic volatile organic compound (BVOC) emissions were calculated using the Model of Emissions of Gases and Aerosols from Nature (MEGANv2.1; Guenther et al., 2012). This model is driven by meteorological variables such as hourly temperature, solar radiation, humidity, wind speed, soil moisture and land cover data, including leaf area index and plant function type, as available in the Community Land Model 4.0. Eight-day average satellite data at $0.25^{\circ} \times 0.25^{\circ}$ resolution were pre-processed and made available from the TERRA/MODIS satellite system. Sixteen plant function types including needle-leaved evergreen, needle- 
leaved deciduous, broad-leaved evergreen, broad-leaved deciduous, grass and crop for different climatic zones were prepared for this study at $0.25^{\circ} \times 0.25^{\circ}$ resolution together with the global emission factors of $\alpha$-pinene, $\beta$-pinene, 3 -carene, isoprene, limonene, 232-methylbutenol, myrcene, $\mathrm{NO}_{x}, t-\beta$ ocimene and sabinene. Common BVOC species such as isoprene, terpene, sesquiterpene, xylene and toluene were obtained for each hour and cell in the domain.

\subsubsection{VBS scheme}

A new VBS scheme is available in the CAMx model to describe changes in oxidation state and volatility. A total of four basis sets simulate the evolution of organic aerosol in the atmosphere (Koo et al., 2014). POA emissions were split in hydrocarbon-like organic aerosol (HOA) and biomass burning organic aerosol (BBOA) emissions and allocated in two different basis sets. HOA-like emissions include emissions from all SNAP sectors except SNAP2 (nonindustrial combustion plants) and SNAP10 (agriculture), which were assigned to BBOA-like emissions. Two other sets were used in the model to allocate secondary organic aerosol from anthropogenic (ASOA) (i.e. xylene and toluene) and biogenic (BSOA) (i.e. isoprene, monoterpene and sesquiterpene) gaseous precursors. These two sets also allocate oxidation products of POA vapours from each of the two primary sets (HOA-like and BBOA-like). The 2-D volatility space retrieved by Donahue et al. (2011, 2012a, b) was used to distribute the organic molecular structures for each of the volatility bins and different sets (Table S1 in the Supplement). Five volatility bins represent the range of SVOCs ranging from $10^{-1} \mu \mathrm{g} \mathrm{m}^{-3}$ to $10^{3} \mu \mathrm{g} \mathrm{m}^{-3}$ in saturation concentrations $\left(C^{*}\right)$. Oxidation processes are modelled by shifting $C^{*}$ by a factor of 10 in the next lower volatility bin, increasing the oxidation state and reducing the carbon number to account for fragmentation. $\mathrm{OH}$ reaction rates are assumed to be $4 \times 10^{-11} \mathrm{~cm}^{3}$ molecule ${ }^{-1} \mathrm{~s}^{-1}$ for the reaction of semivolatile primary vapours with $\mathrm{OH}$ and $2 \times 10^{-11}$ for further aging of ASOA and POA vapours from HOA-like emissions. More details about the VBS parameterization in CAMx can be found in Koo et al. (2014). Further aging of BSOA is not considered in this study, based on previous modelling results showing overprediction of OA when such process is taken into account (Lane et al., 2008; Murphy and Pandis, 2009). This implies that also further aging of POA vapours from BBOA-like emissions was not considered since it is performed in the same basis set. In this work we focus on the effects of a VBS framework on the total OA fraction. Aging processes and alternative VBS implementations will be discussed together with SOA and POA components in a following paper (Ciarelli et al., 2016). Three sensitivity tests were performed with different assumptions on the volatility distributions (Table 1).

- NOVBS: primary organic aerosol was assumed to be nonvolatile. Biogenic (isoprene, monoterpenes and sesquiterpenes) and anthropogenic (xylene, toluene and other aromatics) volatile organic compounds were used as precursors for secondary organic aerosol. Partitioning of condensable gases to secondary organic aerosol was calculated using a semivolatile equilibrium approach (Strader, 1999).

- VBS_ROB: primary organic aerosol was assumed to be volatile and undergo chemical oxidation. The volatility distribution estimated by Robinson et al. (2007) was applied to HOA-like and BBOA-like emissions. Emissions of IVOCs were assumed to be 1.5 times those of POA as suggested by Robinson et al. (2007).

- VBS_BC: primary organic aerosol was assumed to be volatile and undergo chemical oxidation using the approach of Shrivastava et al. (2011) and Tsimpidi et al. (2010). The total primary emissions are roughly 3 times higher than in VBS_ROB. Different volatility distributions were applied for HOA- and BBOA-like emissions. IVOCs were assumed to be 1.5 times the amount of POA. This implies that for this scenario the SVOC + IVOC mass added is equal to 7.5 times the initial amount of POA. This represents the base case scenario used to evaluate gas phase and $\mathrm{PM}_{2.5}$ model performance.

Based on the VBS_BC base case scenario, two other sensitivity tests were performed with respect to emissions:

- VBS_BC_2xBVOC increased BVOCs emissions by a factor of 2

- VBS_BC_2xBBOA increased BBOA-like emissions by a factor of 2 .

\subsection{Statistical methods}

Statistical procedures as available in the Atmospheric Model Evaluation Tool (AMET; Appel et al., 2010) were used in this study to evaluate model performance. Daily ambient measurements of main gas phase species, i.e. $\mathrm{O}_{3}, \mathrm{NO}_{2}, \mathrm{CO}, \mathrm{SO}_{2}$ and fine particulate matter $\left(\mathrm{PM}_{2.5}\right)$, were extracted from the AirBase database in Europe and statistics reported in terms of mean bias (MB), mean error (ME), mean fractional bias (MFB) mean fractional error (MFE) and correlation coefficient $(r)$.

Due to the coarse grid resolution, only rural-background stations, defined as stations far from city sources of air pollution with pollution levels determined by the integrated contribution from all sources upwind of the station (ETC/ACC, 2004/7), with at least $80 \%$ daily average observations available were considered for the statistical analysis. For $\mathrm{PM}_{2.5}$ this resulted in 48 stations available for June 2006, 56 for January-February 2007, 90 for September-October 2008 and 110 stations for February-March 2009. PM 2.5 components were further evaluated for the February-March 2009 
Table 1. Volatility distributions used for different scenarios.

\begin{tabular}{|c|c|c|c|c|c|c|}
\hline \multirow[t]{2}{*}{ Scenarios } & \multirow[t]{2}{*}{ POA emission sources } & \multicolumn{5}{|c|}{$\begin{array}{l}\text { Emission fraction for volatility bin with } C^{*} \\
\text { of }\end{array}$} \\
\hline & & $0^{\mathrm{a}}$ & 1 & 10 & 100 & 1000 \\
\hline $\begin{array}{l}\text { NOVBS } \\
\text { (nonvolatile } \\
\text { CAMxv5.40) }\end{array}$ & $\begin{array}{l}\text { HOA-like } \\
\text { BBOA-like }\end{array}$ & $\begin{array}{l}1.00 \\
1.00\end{array}$ & - & - & - & - \\
\hline VBS_ROB & HOA-like & 0.09 & 0.09 & 0.14 & 0.18 & 0.5 \\
\hline (Robinson et al., 2007) & BBOA-like & 0.09 & 0.09 & 0.14 & 0.18 & 0.5 \\
\hline VBS_BC & HOA-like & 0.40 & 0.26 & 0.40 & 0.51 & 1.43 \\
\hline $\begin{array}{l}\text { (Tsimpidi et al., 2010; } \\
\text { Shrivastava et al., 2011) }\end{array}$ & BBOA-like & 0.27 & 0.27 & 0.42 & 0.54 & 1.50 \\
\hline
\end{tabular}

a Properties of the lowest volatility bins refer to all OA with $C^{*} \leq 0.1 \mu \mathrm{g} \mathrm{m}^{-3}$ (non-volatile OA).

period where comprehensive high-resolution AMS measurements at 11 European sites were available, i.e. at Barcelona, Cabauw, Chilbolton, Helsinki, Hyytiälä, Mace Head, Melpitz, Montseny, Payerne, Puy de Dôme and Vavihill (Crippa et al., 2014).

\section{Results and discussions}

\subsection{Model evaluation}

Model performance metrics for gas phase species $\mathrm{CO}, \mathrm{NO}_{2}$, $\mathrm{O}_{3}$ and $\mathrm{SO}_{2}$ as well as for $\mathrm{PM}_{2.5}$ are reported in Table 2 and they refer to the base case VBS_BC.

\subsection{1 $\mathrm{NO}_{2}$ and $\mathrm{O}_{3}$}

$\mathrm{NO}_{2}$ was found to be underpredicted for all the four periods with mean fractional bias between -54 and $-28 \%$ and $\mathrm{NO}_{2}$ concentrations being particularly underpredicted during June 2006. Evaluation of the EDIII model intercomparison exercise showed that all models performed similarly for $\mathrm{NO}_{2}$ in terms of correlation with $r$ values in the range $0.6-0.7$ and the spatial correlation was much higher in the range $0.7-0.9$ for all models (Bessagnet et al., 2016) with a general underestimation in the afternoon. The $\mathrm{NO}_{2}$ performance could be influenced by several factors.

- Uncertainties in the emission inventories. Although $\mathrm{NO}_{x}$ emission estimates in Europe are thought to have an uncertainty of about $\pm 20 \%$, the complete dataset used in the inventories has much higher uncertainty (Kuenen et al., 2014). A recent study identified a significant discrepancy between emission estimates and actual flux measurements, with the highest underestimation being a factor of two in central London mainly due to underrepresentation of real world road traffic emissions (Vaughan et al., 2016)
- The relatively coarse resolution of the domain may result in too low $\mathrm{NO}_{x}$ emissions or isolated local events that the model cannot resolve. We report daily average time series of $\mathrm{NO}_{2}$ for the period of FebruaryMarch 2009 for stations in Table 2 as well as daily average time series of $\mathrm{NO}_{2}$ for stations not exceeding $5 \mathrm{ppb}$ (which represents $92 \%$ of the stations in Table 2) (Fig. S1 in the Supplement). The model performance for $\mathrm{NO}_{2}$ significantly improved when the $5 \mathrm{ppb}$ threshold was applied to the dataset. An emission map of NO for 1 March 2009 at 06:00 is reported in Fig. S2. High emissions of NO are predicted in the Benelux area, Po Valley, Germany and in some of the eastern European countries. High NO emissions due to ship traffic are also visible, especially in the Mediterranean Sea.

- Possible positive artefacts in the chemiluminescence methods for measuring $\mathrm{NO}_{2}$ may also occur when $\mathrm{NO}_{2}$ is catalytically converted to $\mathrm{NO}$ on the molybdenum surface, leading to an overprediction of measured $\mathrm{NO}_{2}$ concentrations (Steinbacher et al., 2007; Villena et al., 2012)

- Moreover, an evaluation of planetary boundary layer height (PBLH) within the EDIII shows that although the PBLH was quite well represented in general in the ECMWF IFS meteorological fields, CAMx tends to underestimate the night-time minima and to overestimate some daytime peaks, overpredicting the dilution of daytime $\mathrm{NO}_{2}$ concentrations, whereas the wind speed was relatively well reproduced (Bessagnet et al., 2016).

$\mathrm{O}_{3}$ concentrations were found to be overpredicted for all the four periods with a mean fractional bias ranging from 2 to $48 \%$. Especially in June 2006, when the photochemical activity is higher, the general underprediction of $\mathrm{NO}_{x}$ in the whole domain reduces the $\mathrm{O}_{3}$ titration potential during nighttime.

Model performance for $\mathrm{O}_{3}$ is also strongly influenced by long-range transport, especially during the winter periods 
Table 2. Model gas phase and $\mathrm{PM}_{2.5}$ performance for the EDIII field campaigns (base case VBS_BC).

\begin{tabular}{|c|c|c|c|c|c|c|c|c|}
\hline Species & $\begin{array}{r}\text { Number of } \\
\text { sites }\end{array}$ & $\begin{array}{r}\text { Observed mean } \\
(\mathrm{ppb}) \\
\left(\mu \mathrm{g} \mathrm{m}^{-3} \text { for } \mathrm{PM}_{2.5}\right)\end{array}$ & $\begin{array}{r}\text { Modelled mean } \\
(\mathrm{ppb}) \\
\left(\mu \mathrm{g} \mathrm{m}^{-3} \text { for } \mathrm{PM}_{2.5}\right)\end{array}$ & $\begin{array}{r}\mathrm{MB} \\
(\mathrm{ppb}) \\
\left(\mu \mathrm{g} \mathrm{m}^{-3} \text { for } \mathrm{PM}_{2.5}\right)\end{array}$ & $\begin{array}{r}\mathrm{ME} \\
(\mathrm{ppb}) \\
\left(\mu \mathrm{g} \mathrm{m}^{-3} \text { for } \mathrm{PM}_{2.5}\right)\end{array}$ & $\begin{array}{r}\text { MFB } \\
{[-]}\end{array}$ & $\begin{array}{r}\text { MFE } \\
{[-]}\end{array}$ & $r$ \\
\hline \multicolumn{9}{|c|}{ June 2006} \\
\hline $\mathrm{CO}$ & 36 & 192.0 & 158.0 & -34.2 & 80.7 & -0.12 & 0.36 & 0.20 \\
\hline $\mathrm{NO}_{2}$ & 320 & 4.1 & 2.3 & -1.9 & 2.2 & -0.54 & 0.68 & 0.55 \\
\hline $\mathrm{O}_{3}$ & 460 & 42.3 & 51.2 & 8.9 & 10.8 & 0.21 & 0.24 & 0.57 \\
\hline $\mathrm{PM}_{2.5}$ & 48 & 12.0 & 11.7 & -0.3 & 4.5 & -0.07 & 0.39 & 0.55 \\
\hline $\mathrm{SO}_{2}$ & 263 & 1.0 & 1.2 & 0.2 & 0.7 & 0.14 & 0.67 & 0.52 \\
\hline \multicolumn{9}{|c|}{ January-February 2007} \\
\hline $\mathrm{CO}$ & 45 & 248.0 & 191.0 & -57.8 & 107.0 & -0.11 & 0.37 & 0.21 \\
\hline $\mathrm{NO}_{2}$ & 337 & 6.5 & 4.4 & -2.2 & 3.2 & -0.28 & 0.57 & 0.68 \\
\hline $\mathrm{O}_{3}$ & 455 & 23.5 & 35.8 & 12.3 & 12.6 & 0.48 & 0.49 & 0.61 \\
\hline $\mathrm{PM}_{2.5}$ & 56 & 11.7 & 12.8 & 1.0 & 6.1 & -0.04 & 0.56 & 0.69 \\
\hline $\mathrm{SO}_{2}$ & 271 & 1.3 & 1.7 & 0.4 & 1.1 & 0.36 & 0.75 & 0.46 \\
\hline \multicolumn{9}{|c|}{ September-October 2008} \\
\hline $\mathrm{CO}$ & 53 & 208.0 & 136.0 & -72.0 & 91.4 & -0.31 & 0.48 & 0.27 \\
\hline $\mathrm{NO}_{2}$ & 370 & 5.3 & 3.7 & -1.7 & 2.5 & -0.28 & 0.56 & 0.62 \\
\hline $\mathrm{O}_{3}$ & 465 & 24.3 & 32.5 & 8.2 & 9.6 & 0.32 & 0.37 & 0.50 \\
\hline $\mathrm{PM}_{2.5}$ & 90 & 13.0 & 14.1 & 1.0 & 5.7 & $<0.01$ & 0.46 & 0.76 \\
\hline $\mathrm{SO}_{2}$ & 256 & 0.9 & 1.1 & 0.2 & 0.8 & 0.25 & 0.74 & 0.37 \\
\hline \multicolumn{9}{|c|}{ February-March 2009} \\
\hline $\mathrm{CO}$ & 57 & 262.0 & 170.0 & -91.6 & 119.0 & -0.26 & 0.48 & 0.37 \\
\hline $\mathrm{NO}_{2}$ & 380 & 6.0 & 3.9 & -2.0 & 2.8 & -0.33 & 0.56 & 0.61 \\
\hline $\mathrm{O}_{3}$ & 488 & 32.7 & 33.0 & 0.2 & 7.1 & 0.02 & 0.23 & 0.55 \\
\hline $\mathrm{PM}_{2.5}$ & 110 & 15.1 & 13.0 & -2.1 & 6.4 & -0.13 & 0.50 & 0.71 \\
\hline $\mathrm{SO}_{2}$ & 257 & 1.0 & 1.3 & 0.3 & 0.9 & 0.23 & 0.76 & 0.45 \\
\hline
\end{tabular}

when the local chemical production of $\mathrm{O}_{3}$ is limited. Figure S3 shows the model performance at the Mace Head station located on the western coast of Ireland for all the four periods. Especially in January-February $2007 \mathrm{O}_{3}$ concentrations were found to be overpredicted by about 10 to $20 \mathrm{ppb}$, indicating that boundary conditions for $\mathrm{O}_{3}$ were probably not well represented. In June 2006 and September-October 2008 $\mathrm{O}_{3}$ was relatively well captured at Mace Head, suggesting that the observed positive bias in $\mathrm{O}_{3}$ concentrations might arise from insufficient $\mathrm{NO}_{x}$ emissions to undergo titration during night-time as well as not correctly represented planetary boundary layer dynamics. In February-March 2009 the model tends to underpredict the $\mathrm{O}_{3}$ concentration at Mace Head and overall the $\mathrm{O}_{3}$ model performance shows the lowest bias (2\%). Eventually, the underprediction of $\mathrm{O}_{3}$ in the boundary condition may counteract the already mentioned deficiencies related to insufficient $\mathrm{NO}_{x}$ emissions.

\subsection{2 $\mathrm{SO}_{2}$ and $\mathrm{CO}$}

$\mathrm{SO}_{2}$ concentrations were found to be slightly overpredicted for all the four periods, with a mean fractional bias ranging from 14 to $36 \%$ for $\mathrm{SO}_{2}$. The daily variations of modelled and measured $\mathrm{SO}_{2}$ concentrations for February-March 2009 are reported as well in Fig. S1 (lower panel) for the stations in Table 2. In general, the daily variations of modelled and measured $\mathrm{SO}_{2}$ concentrations agree relatively well with each other throughout the period.

Most of the $\mathrm{SO}_{2}$ emissions arise from high stack point sources which have injection heights of a few hundred metres. It might be that the vertical distribution of $\mathrm{SO}_{2}$ might affect the model performance in particular near the harbours and coastal areas where ship emissions were allocated in the second layer of the model domain (extending from $\sim 20$ to $50 \mathrm{~m}$ above ground level), whereas they can reach up to $58 \mathrm{~m}$ in deep draft vessels (Starcrest Consulting Group, 2004) and also undergo plume rise. Insufficient conversion to sulfate or too low deposition processes might also positively bias the model performance for $\mathrm{SO}_{2}$.

$\mathrm{CO}$ was slightly underpredicted for all periods (mean fractional bias between -11 and $-31 \%$ ), with highest values during the September-October 2008 period $(-31 \%)$. The late summer-autumn period is known to be influenced by agricultural open field burning activities which might be missing from standard emission inventories.

In general, for both $\mathrm{SO}_{2}$ and $\mathrm{CO}$, the model showed lower correlation coefficients with respect to other gas phase species ( $r$ values from 0.20 and 0.37 for $\mathrm{CO}$ and from 0.37 to 0.52 for $\mathrm{SO}_{2}$ ). 


\subsection{3 $\mathbf{P M}_{2.5}$}

Of all investigated variables, CAMx shows the best statistical performance for $\mathrm{PM}_{2.5}$. For all four periods the acceptable model performance criteria recommended by Boylan and Russell (2006) for aerosols were met (MFE $\leq+75 \%$ and $-60 \%<\mathrm{MFB}<+60 \%)$. The fractional bias ranges from less than $1 \%$ in September-October 2008 up to $-13 \%$ in February-March 2009. Also the recommended model performance goals $(\mathrm{MFE} \leq+50 \%$ and $-30 \%<\mathrm{MFB}<+30 \%$ ) were met for all periods except for January 2007. Modelled average $\mathrm{PM}_{2.5}$ concentrations are shown in Fig. 1. A different spatial distribution is seen for summer and winter. In June 2006 the model predicts higher concentrations in the southern part of the domain, especially over the Mediterranean Sea and North Africa (up to $35 \mu \mathrm{g} \mathrm{m}^{-3}$ ). In contrast, the highest concentrations were predicted in the Po Valley area (above $40 \mathrm{\mu g} \mathrm{m}^{-3}$ ) and in the southern part of Poland during January-February 2007. During the two colder periods (2007 and 2009) elevated concentrations of around $15 \mu \mathrm{g} \mathrm{m}^{-3}$ are also visible close to urban areas such as Paris and Moscow. Figure 2 shows $\mathrm{PM}_{2.5}$ variations at AirBase rural-background sites in terms of medians, 25th and 75th percentiles. In all the four periods CAMx is able to reproduce the observed monthly variation very well with some overprediction occurring mainly from the 14 to the 17 of January 2007 and towards the end of the 2008 period.

\subsection{Detailed evaluation of $\mathrm{PM}_{2.5}$ components in February-March 2009}

The modelled concentrations of non-refractory $\mathrm{PM}_{2.5}$ components were compared against aerosol mass spectrometer measurements at 11 European sites for the FebruaryMarch 2009 period (Crippa et al., 2014). Even though the AMS measures particles with a diameter $D<1 \mu \mathrm{m}$, the difference between the non-refractory $\mathrm{PM}_{1}$ and total $\mathrm{PM}_{2.5}$ mass is in general rather small as shown in Aksoyoglu et al. (2011), at least for situations without exceedingly high air pollution and situations when sea salt makes a large relative contribution to $\mathrm{PM}_{2.5}$. The modelled average total nonrefractory $\mathrm{PM}_{2.5}$ (sum of nitrate, sulfate, ammonium and OA) concentrations match the measurements quite well with a few exceptions (Fig. 3 and Table 3). The model is able to reproduce both high concentrations observed at the urban site Barcelona and low ones at remote sites like Hyytiälä, Finland. Concentrations of inorganic aerosols are overpredicted and OA are underpredicted at most of the stations (with similar behaviour during the other investigated periods; Figs. S4 and S5). Very similar results were also presented by other recent studies (Knote et al., 2011). The effect of different schemes to treat OA is discussed in Sect. 3.3. At the Cabauw site nitrate was the most dominant species (Mensah et al., 2012). Especially at this site the model strongly overpredicts, in particular the nitrate $\left(\mathrm{NO}_{3}^{-}\right)$fraction (by a factor of 3$)$. A sensitivity test with $50 \%$ reduction in ammonia emissions significantly improved the modelled $\mathrm{NO}_{3}^{-}$concentrations at almost all sites (Table S2), suggesting potential uncertainties in $\mathrm{NH}_{3}$ emissions and their seasonal variability. Other potential reasons for the overprediction of $\mathrm{NO}_{3}^{-}$could be related to uncertainties in the removal process of $\mathrm{HNO}_{3}$ as well as the dry deposition velocity of $\mathrm{NH}_{3}$. Substantial overpredictions were found at the higher-altitude site of Montseny and Puy de Dôme when compared with first model layer concentrations ( 200 and $800 \mathrm{~m}$ a.s.l., respectively, at these sites). These sites located at about 720 and $1465 \mathrm{~m}$ a.s.l. are sometimes not within the PBLH during winter periods. At the Montseny site, the relatively coarse resolution of the model could also influence model performance since the site is located in a complex area about $50 \mathrm{~km}$ north-east of Barcelona (Pandolfi et al., 2014). Sulfate concentrations $\left(\mathrm{SO}_{4}^{2-}\right)$ were overpredicted at almost all sites and especially at Mace Head, suggesting that long-range transport of $\mathrm{SO}_{4}^{2-}$ might be positively biased.

Modelled and observed hourly concentrations of $\mathrm{NO}_{3}^{-}$, $\mathrm{SO}_{4}^{2-}$, ammonium $\left(\mathrm{NH}_{4}^{+}\right)$and $\mathrm{OA}$ at Payerne are reported in Fig. 4 for March 2009 together with meteorological parameters in Fig. S6. The model was able to reproduce the meteorological parameters very well for most of the time. The temperature was slightly underpredicted at both nightand daytime (with a maximum of $-2^{\circ} \mathrm{C}$ ), whereas both the monthly variation and the absolute values of wind speed and specific humidity were reproduced well with a few underpredictions of high wind speed (6 and 11 March and towards the end of the simulation). The model was able to capture the three $\mathrm{NO}_{3}^{-}$and $\mathrm{NH}_{4}^{+}$peaks observed around the 7, 18 and 23 March with a general slight overprediction throughout the whole period. Indeed, the underprediction in temperature during day- and night-time could partially explain the overprediction of the $\mathrm{NO}_{3}^{-}$fraction with more $\mathrm{NO}_{3}^{-}$partitioning to the aerosol phase, which also applies to the other stations used in this study. An evaluation of modelled temperature at the European scale for the February-March 2009 period confirmed that the model systematically underpredicted the $2 \mathrm{~m}$ surface temperature (Bessagnet et al., 2014). All the inorganic components were overpredicted during the first 4 days of March 2009 with a peak around 3 March, indicating that the PBLH was probably not correctly reproduced by the model during this period. Although the temporal variation was captured, concentrations of OA were underpredicted throughout all the simulation ( 4.1 and $1.8 \mu \mathrm{g} \mathrm{m}^{-3}$ observed and modelled average concentrations). Analysis of the OA fraction is discussed in the next section.

\subsection{Organic aerosols}

\subsubsection{Sensitivity of OA to the VBS scheme}

In this section, effects of different parameterizations of the organic aerosol module on the modelled OA concentrations 
Table 3. Statistical analysis of nitrate, ammonium, sulfate and organic aerosol for the base case (VBS_BC) for February-March 2009 at different AMS sites.

\begin{tabular}{|c|c|c|c|c|c|c|}
\hline Site & $\begin{array}{r}\text { Mean observed } \\
\left(\mu \mathrm{g} \mathrm{m}^{-3}\right)\end{array}$ & $\begin{array}{l}\text { Mean modelled } \\
\qquad\left(\mu \mathrm{g} \mathrm{m}^{-3}\right)\end{array}$ & $\begin{array}{r}\mathrm{MB} \\
\mu \mathrm{g} \mathrm{m}^{-3}\end{array}$ & $\begin{array}{r}\mathrm{ME} \\
\mu \mathrm{g} \mathrm{m}^{-3}\end{array}$ & $\begin{array}{r}\text { MFB } \\
{[-]}\end{array}$ & $\begin{array}{r}\text { MFE } \\
{[-]}\end{array}$ \\
\hline \multicolumn{7}{|c|}{$\mathrm{NO}_{3}^{-}$} \\
\hline Barcelona & 3.6 & 5.8 & 2.2 & 4.0 & 0.35 & 0.98 \\
\hline Cabauw & 2.2 & 6.7 & 4.5 & 4.6 & 0.85 & 1.01 \\
\hline Chilbolton & 2.7 & 4.0 & 1.3 & 2.2 & 0.02 & 0.76 \\
\hline Helsinki & 1.0 & 1.9 & 0.9 & 1.3 & 0.29 & 0.92 \\
\hline Hyytiälä & 0.2 & 1.0 & 0.8 & 0.8 & 0.21 & 1.09 \\
\hline Mace Head & 0.6 & 1.7 & 1.1 & 1.1 & 0.14 & 0.70 \\
\hline Melpitz & 3.1 & 4.3 & 1.3 & 2.4 & 0.35 & 0.71 \\
\hline Montseny & 3.1 & 5.9 & 2.8 & 4.3 & 0.38 & 1.00 \\
\hline Payerne & 3.9 & 5.7 & 1.8 & 2.8 & 0.34 & 0.61 \\
\hline Puy de Dôme & 0.9 & 2.7 & 1.8 & 2.2 & 1.13 & 1.30 \\
\hline Vavihill & 2.8 & 3.7 & 0.9 & 2.2 & 0.14 & 0.78 \\
\hline \multicolumn{7}{|c|}{$\mathrm{NH}_{4}^{+}$} \\
\hline Barcelona & 1.6 & 2.5 & 0.9 & 1.4 & 0.42 & 0.71 \\
\hline Cabauw & 1.0 & 2.7 & 1.7 & 1.8 & 0.95 & 0.97 \\
\hline Chilbolton & 1.3 & 2.0 & 0.7 & 1.0 & 0.39 & 0.61 \\
\hline Helsinki & 0.8 & 1.3 & 0.5 & 0.6 & 0.51 & 0.60 \\
\hline Hyytiälä & 0.4 & 0.8 & 0.4 & 0.5 & 0.55 & 0.70 \\
\hline Melpitz & 1.4 & 2.1 & 0.7 & 1.1 & 0.45 & 0.69 \\
\hline Montseny & 1.7 & 2.6 & 0.9 & 1.6 & 0.39 & 0.74 \\
\hline Payerne & 1.7 & 2.5 & 0.8 & 1.2 & 0.36 & 0.56 \\
\hline Puy de Dôme & 0.7 & 1.2 & 0.5 & 0.9 & 0.83 & 1.07 \\
\hline Vavihill & 1.6 & 1.9 & 0.4 & 0.9 & 0.17 & 0.56 \\
\hline \multicolumn{7}{|c|}{$\mathrm{SO}_{4}^{2-}$} \\
\hline Barcelona & 2.7 & 2.3 & -0.4 & 1.3 & -0.19 & 0.48 \\
\hline Cabauw & 1.0 & 2.1 & 1.1 & 1.3 & 0.73 & 0.85 \\
\hline Chilbolton & 1.3 & 2.2 & 0.9 & 1.3 & 0.45 & 0.70 \\
\hline Helsinki & 2.4 & 2.2 & -0.2 & 0.9 & -0.04 & 0.43 \\
\hline Hyytiälä & 1.4 & 1.7 & 0.3 & 0.7 & 0.09 & 0.58 \\
\hline Mace Head & 0.4 & 1.2 & 0.8 & 0.9 & 1.04 & 1.12 \\
\hline Melpitz & 1.1 & 2.2 & 1.1 & 1.4 & 0.54 & 0.76 \\
\hline Montseny & 1.4 & 2.3 & 1.0 & 1.2 & 0.55 & 0.64 \\
\hline Payerne & 1.1 & 2.1 & 1.1 & 1.2 & 0.62 & 0.70 \\
\hline Puy de Dôme & 0.4 & 1.1 & 0.8 & 0.8 & 1.14 & 1.19 \\
\hline Vavihill & 1.6 & 2.3 & 0.7 & 1.1 & 0.18 & 0.54 \\
\hline \multicolumn{7}{|c|}{$\mathrm{OA}$} \\
\hline Barcelona & 8.2 & 3.1 & -5.1 & 5.2 & -0.80 & 0.82 \\
\hline Cabauw & 1.2 & 1.1 & -0.1 & 0.5 & -0.13 & 0.50 \\
\hline Chilbolton & 2.4 & 0.7 & -1.7 & 1.7 & -1.09 & 1.10 \\
\hline Helsinki & 2.7 & 2.9 & 0.3 & 1.6 & 0.08 & 0.62 \\
\hline Hyytiälä & 1.3 & 1.0 & -0.3 & 0.5 & -0.48 & 0.60 \\
\hline Mace Head & 0.8 & 0.4 & -0.4 & 0.4 & -0.29 & 0.70 \\
\hline Melpitz & 1.5 & 0.5 & -1.0 & 1.0 & -0.94 & 0.97 \\
\hline Montseny & 3.1 & 3.9 & 0.9 & 1.9 & 0.31 & 0.57 \\
\hline Payerne & 4.1 & 1.8 & -2.3 & 2.4 & -0.85 & 0.90 \\
\hline Puy de Dôme & 0.6 & 1.4 & 0.8 & 1.0 & 0.68 & 0.91 \\
\hline Vavihill & 3.9 & 1.4 & -2.5 & 2.5 & -1.04 & 1.04 \\
\hline
\end{tabular}



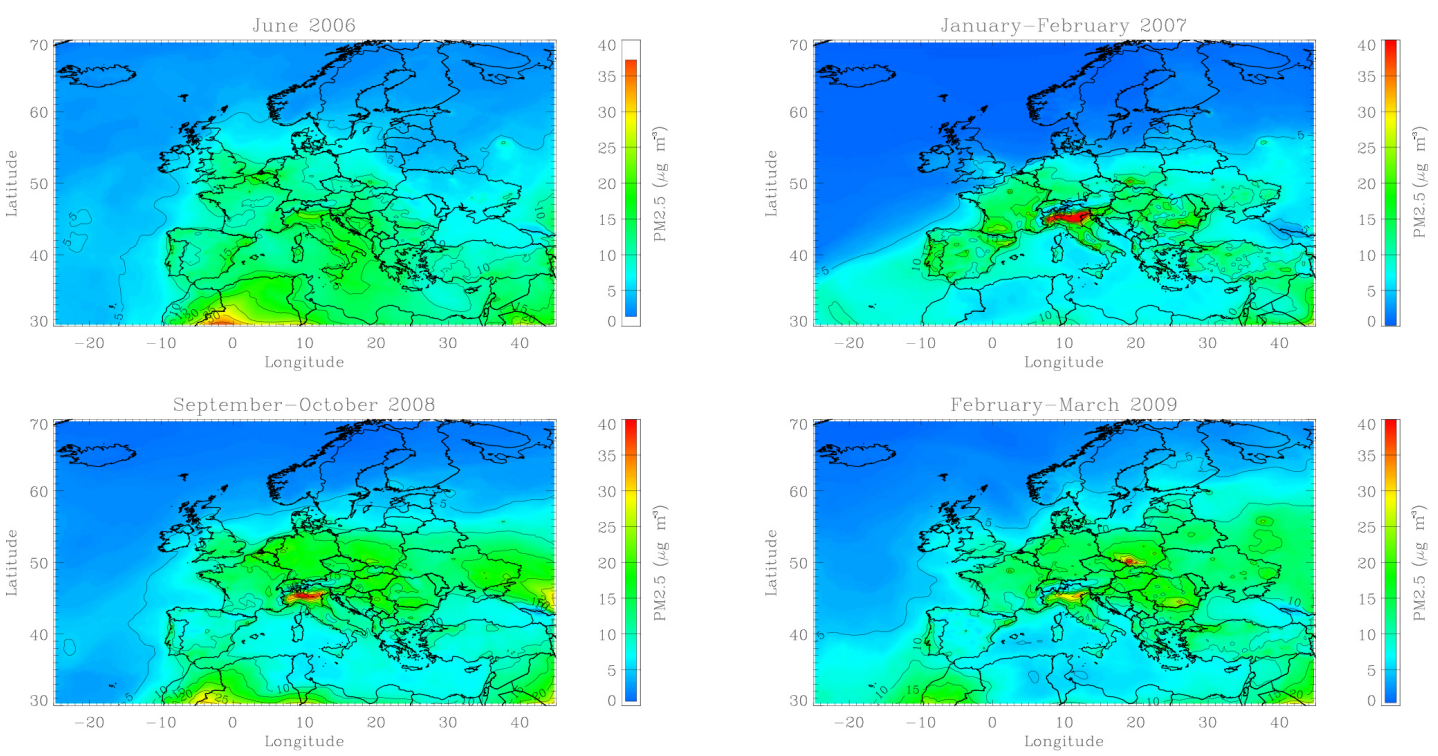

Figure 1. Modelled average $\mathrm{PM}_{2.5}$ concentrations for June 2006, January-February 2007, September-October 2008 and FebruaryMarch 2009 (top to bottom and left to right) based on the base case (VBS_BC). Note that the colour scale was limited to a maximum of $40 \mu \mathrm{g} \mathrm{m}^{-3}$ to facilitate comparison of the panels.

Table 4. Statistical analysis of OA for NOVBS, VBS_ROB and VBS_BC scenarios for the 11 AMS sites for February-March 2009.

\begin{tabular}{lrrrrrr}
\hline Scenario & $\begin{array}{r}\text { Mean observed OA } \\
\left(\mu \mathrm{g} \mathrm{m}^{-3}\right)\end{array}$ & $\begin{array}{r}\text { Mean modelled OA } \\
\left(\mu \mathrm{g} \mathrm{m}^{-3}\right)\end{array}$ & $\begin{array}{r}\text { MB } \\
\left(\mu \mathrm{g} \mathrm{m}^{-3}\right)\end{array}$ & $\begin{array}{r}\text { ME } \\
\left(\mu \mathrm{g} \mathrm{m}^{-3}\right)\end{array}$ & $\begin{array}{r}\text { MFB } \\
{[-]}\end{array}$ & $\begin{array}{r}\text { MFE } \\
{[-]}\end{array}$ \\
\hline NOVBS & 3.0 & 1.2 & -1.8 & 2.0 & -0.66 & 0.88 \\
VBS_ROB & 3.0 & 0.7 & -2.3 & 2.4 & -1.08 & 1.19 \\
VBS_BC (base case) & 3.0 & 1.7 & -1.2 & 1.8 & -0.47 & 0.79 \\
\hline
\end{tabular}

are discussed. The scatter plots in Fig. 5 show a comparison of daily average OA concentrations against the same AMS measurements as in Table 3 during February-March 2009. Statistics for each scenario are reported in Table 4. When the semivolatile dynamics of primary organic aerosol is not taken into account (scenario NOVBS), the model underpredicts OA concentrations (MFB: $-66 \%$ ) with observed and modelled average concentrations of 3.0 and $1.2 \mu \mathrm{g} \mathrm{m}{ }^{-3}$, respectively. In the VBS_ROB scenario POA emissions are allowed to evaporate following the volatility distribution proposed by Robinson et al. (2007) and to undergo chemical oxidation. In this case modelled OA concentrations decrease by about $42 \%$ with respect to NOVBS, predicting an average OA concentration of $0.7 \mu \mathrm{g} \mathrm{m}^{-3}$. In contrast, the VBS_BC scenario improves the OA model performance increasing the OA concentrations by about $42 \%$ with respect to NOVBS. Predicted OA concentrations are found to be $1.7 \mu \mathrm{g} \mathrm{m}^{-3}$ on average (MFB: $-47 \%$ ). Similar behaviour during winter periods was also shown in recent studies where the same VBS scheme was applied in the US domain (Koo et al., 2014).
Figure 6 shows the modelled total OA concentration over Europe using NOVBS, VBS_ROB and VBS_BC scenarios. The model predicts high OA values in the eastern part of the domain as well as over Portugal, France and the Po Valley (VBS_BC). Some hotspots around large urban areas are also visible, i.e. Paris and Moscow. Higher OA concentrations in the southern part of the domain are observed in the VBS_BC case, likely because of higher temperature and more $\mathrm{OH}$ radicals available in that part of the domain leading to an increase in the total organic mass upon reaction with organic vapours. This is in line with the results of Fountoukis et al. (2014) for the February-March 2009 period even though their study predicts lower concentrations over the Po Valley. Even though model input data and parameterizations are not the same, the VBS_BC case in particular uses a very similar volatility distribution to Fountoukis et al. (2014). Our study predicts relatively lower OA concentrations (MFB: -0.47 ; MFE: 0.79) compared to those reported by Fountoukis et al. (2014) (MFB: 0.02; MFE: 0.68) for February-March 2009. Unlike Fountoukis et al. (2014) 

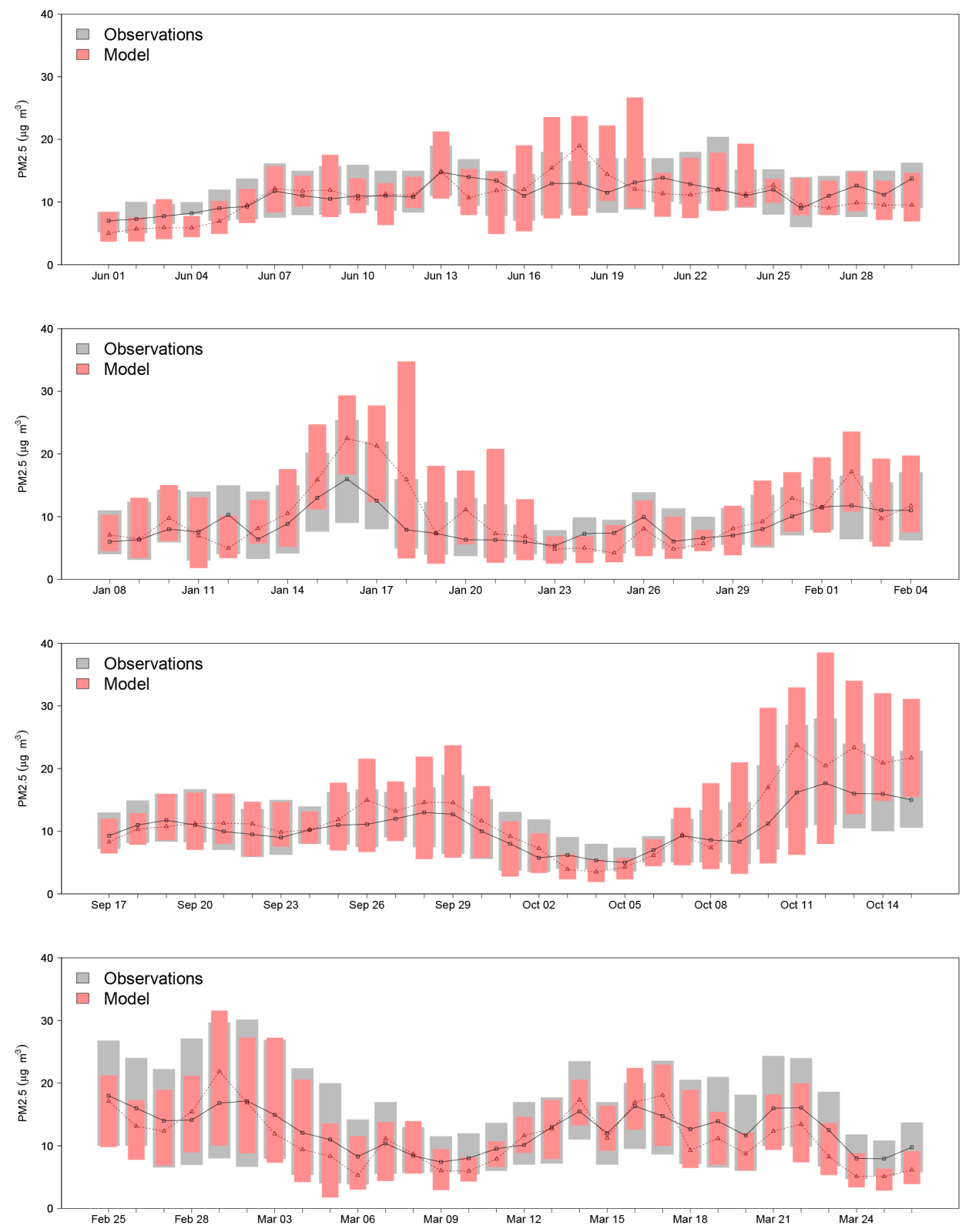

Figure 2. Comparison of modelled (red) and measured (grey) $\mathrm{PM}_{2.5}$ concentrations at AirBase rural-background sites. The extent of the bars indicates the 25th and 75th percentiles. The black and red lines are observed and modelled medians, respectively. The numbers of sites are 48, 56, 90 and 110 from top to bottom. Based on the base case (VBS_BC).

our study does not include fire emissions and marine organic aerosol, which may partially explain the differences. Figure 7 shows hourly modelled and observed OA concentration at Payerne for March 2009 and June 2006. In March 2009 VBS_ROB results are lower than those in NOVBS whereas OA concentrations in VBS_BC case are higher (see Supplement Fig. S8 and Table S3 for average concentrations and statistics). In June 2006, the OA mass in VBS_ROB is lower than those in NOVBS while VBS_BC predicts similar concentrations as the NOVBS scenario $\left(2.4\right.$ and $2.6 \mu \mathrm{g} \mathrm{m}^{-3}$, respectively, Fig. S9 and Table S4). It has to be noted that the
NOVBS scenario predicts slightly lower OA concentration for June 2006 in Payerne with respect to our previous application (Aksoyoglu et al., 2011), mainly because of a different biogenic model being used which yields lower monoterpene and sesquiterpene emissions. Since both BVOCs and BBOAlike emissions are highly uncertain, sensitivity tests with increased biogenic and anthropogenic emissions were performed and results discussed in the next section (Sect. 3.3.2). 

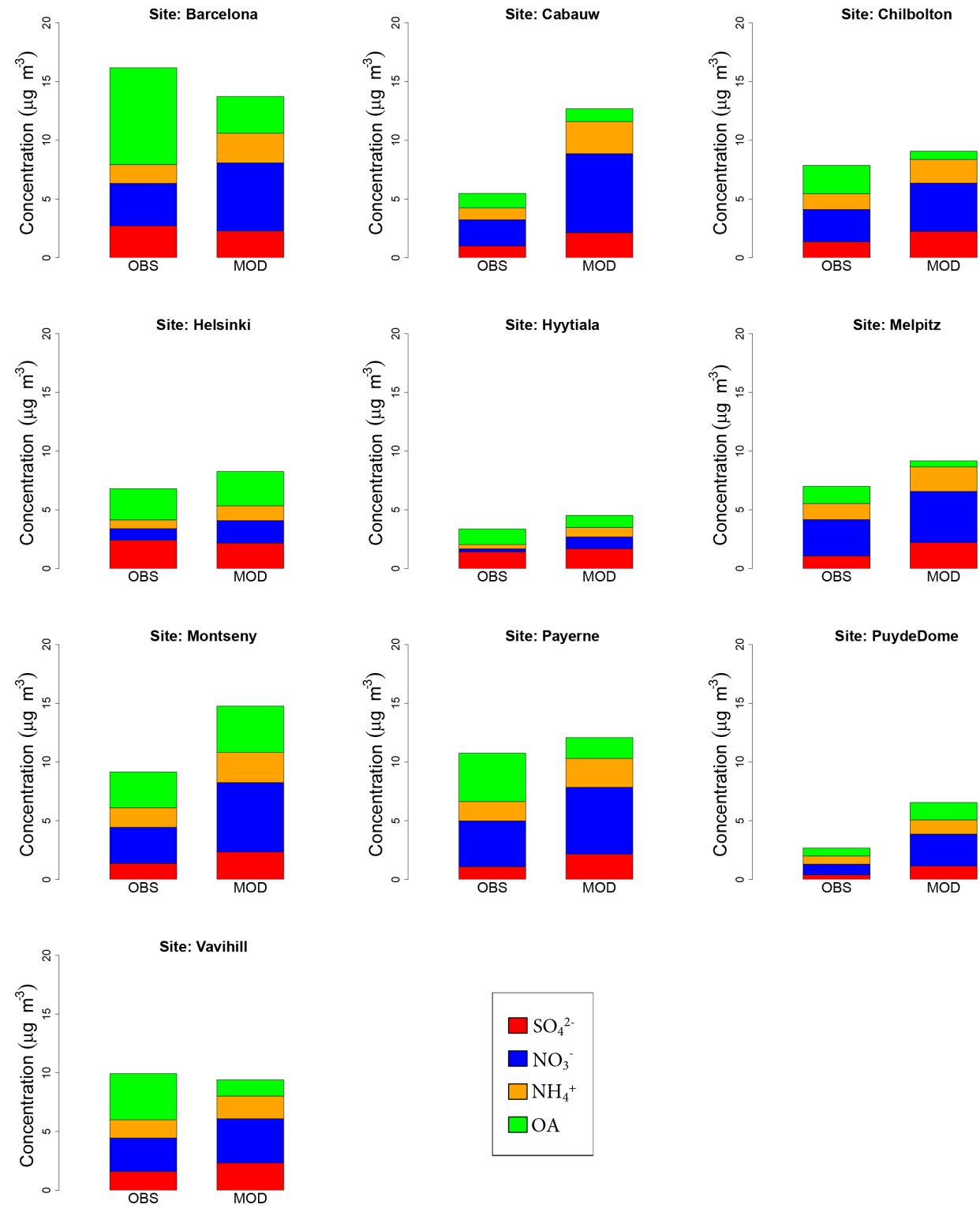

Figure 3. Comparison of observed (OBS) non-refractory $\mathrm{PM}_{1}$ and modelled (MOD) non-refractory $\mathrm{PM}_{2.5}$ at 10 AMS sites in Europe during February-March 2009. Mace Head is reported only in Table 3 since the ammonium component is not available.

\subsubsection{Sensitivity of OA to BBOA-like and BVOC emissions}

Emissions of BVOCs compounds (i.e. monoterpenes, isoprene and sesquiterpenes) were doubled in scenario VBS_BC_2xBVOC, whilst primary organic aerosol emissions from SNAP2 and SNAP10 (BBOA-like) were doubled in scenario VBS_BC_2xBBOA, with other emissions and processes represented as in VBS_BC. Figure 8 shows modelled and observed $\mathrm{OA}$ daily average concentrations for the VBS_BC, VBS_BC_2xBVOC and VBS_BC_2xBBOA scenarios across the sites. Statistics for each scenario are reported in Table 5. Increasing biogenic emissions by a fac- tor of 2 during February-March 2009 resulted in almost no change in the predicted total OA $\left(1.7\right.$ and $1.8 \mu \mathrm{g} \mathrm{m}^{-3}$ for the VBS_BC and VBS_BC_2xBVOC scenarios respectively). In contrast, doubling the BBOA-like emissions (VBS_BC_2xBBOA) during the same period strongly increased the predicted OA mass (up to $2.8 \mathrm{\mu g} \mathrm{m}^{-3}$ on average). As a result the mean fractional bias decreased further, from -47 to $-12 \%$ averaged across the sites. This could eventually confirm other studies in which substantial underpredictions in residential wood burning emissions were underlined (e.g. Bergström et al., 2012). A few points above the $2: 1$ lines in VBS_BC_2xBBOA mainly belong to the sites of Montseny, Puy de Dôme and Helsinki. During winter pe- 
Table 5. Statistical analysis of OA for VBS_BC, VBS_BC_2xBVOC and VBS_BC_2xBBOA scenarios for the 11 AMS sites for FebruaryMarch 2009.

\begin{tabular}{lrrrrrr}
\hline Scenario & $\begin{array}{r}\text { Mean observed OA } \\
\left(\mu \mathrm{g} \mathrm{m}^{-3}\right)\end{array}$ & $\begin{array}{r}\text { Mean modelled OA } \\
\left(\mu \mathrm{g} \mathrm{m}^{-3}\right)\end{array}$ & $\begin{array}{r}\text { MB } \\
\left(\mu \mathrm{g} \mathrm{m}^{-3}\right)\end{array}$ & $\begin{array}{r}\text { ME } \\
\left(\mu \mathrm{g} \mathrm{m}^{-3}\right)\end{array}$ & $\begin{array}{r}\text { MFB } \\
{[-]}\end{array}$ & $\begin{array}{r}\text { MFE } \\
{[-]}\end{array}$ \\
\hline VBS_BC (base case) & 3.0 & 1.7 & -1.2 & 1.8 & -0.47 & 0.79 \\
VBS_BC_2xBVOC & 3.0 & 1.8 & -1.2 & 1.8 & -0.46 & 0.78 \\
VBS_BC_2xBBOA & 3.0 & 2.8 & -0.1 & 1.9 & -0.12 & 0.69 \\
\hline
\end{tabular}
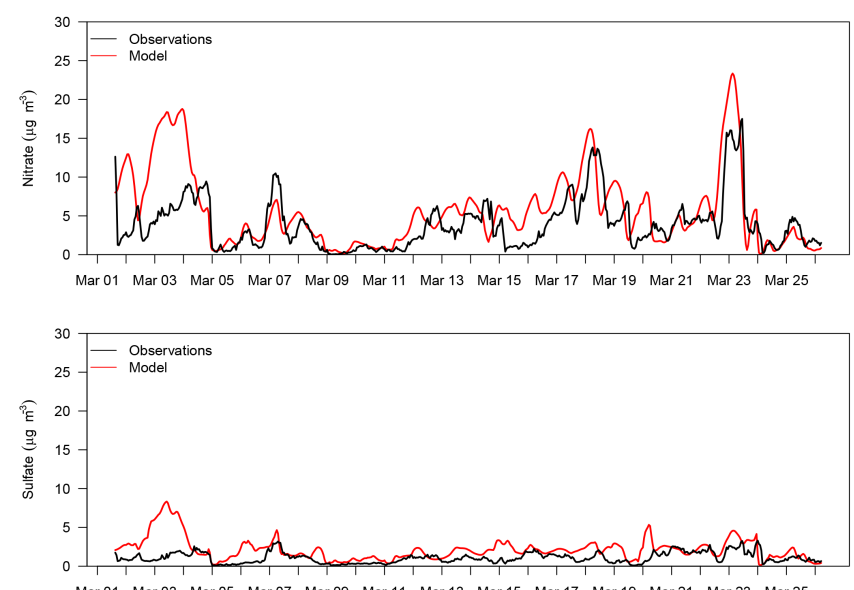

Mar 01 Mar 03 Mar 05 Mar 07 Mar 09 Mar 11 Mar 13 Mar 15 Mar 17 Mar 19 Mar 21 Mar $23 \quad$ Mar 25
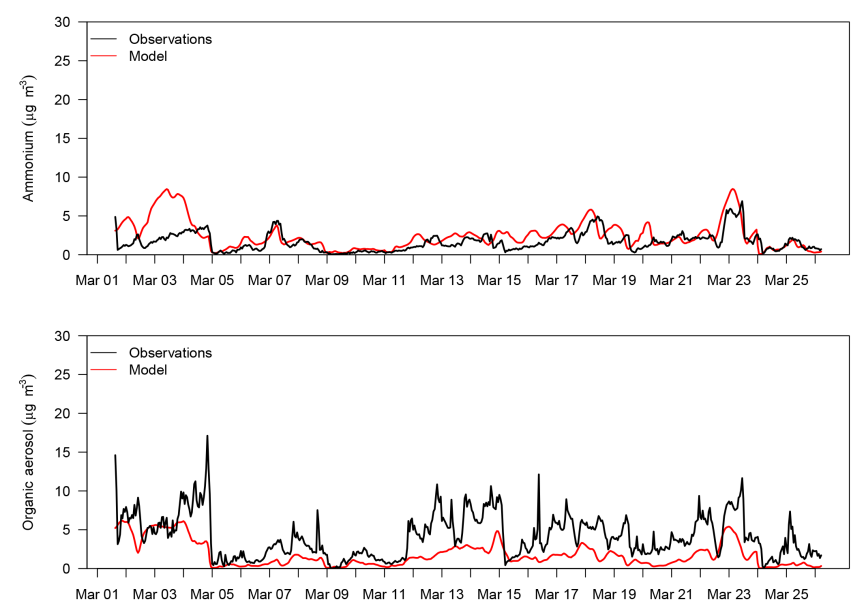

Figure 4. Comparison of observed and modelled nitrate, ammonium, sulfate and organic aerosol at Payerne for March 2009.

riods, it is likely that elevated stations such Montseny and Puy de Dôme are most of the time above the PBLH, as suggested by previous studies for Puy de Dôme (Freney et al., 2011), whereas model concentrations are extracted from the first layer of the model. In Helsinki, BBOA emissions seem to be overestimated or the dispersion underestimated in the model.

Comparison with a warmer period in June 2006 is reported as well for Payerne, where AMS measurements were also available (Fig. 9). In February-March 2009, increasing BBOA-like emissions (VBS_BC_2xBBOA) reduced the fractional bias from $-85 \%$ in VBS_BC to $-37 \%$ (Table S3) with an overprediction occurring during 1-5 of March (Fig. 9, upper panel). As already discussed in Sect. 3.2, it is likely that the vertical mixing processes were not correctly represented by the model since also the inorganic components were overpredicted for the same period. Almost no change in the predicted OA mass was found when biogenic emissions were doubled (scenario VBS_BC_2xBVOC) (Fig. 9, upper panel) due to lower BVOCs emission during winter periods. Increasing BVOCs emissions in June 2006 increased the predicted OA mass at Payerne site, especially during the 12-16 June and towards the end of the simulation period, when higher concentrations and temperature (Fig. S7) were also observed (Fig. 9, lower panel). In contrast, similar OA concentrations were predicted in Payerne for VBS_BC and VBS_BC_2xBBOA during June 2006 (with averages of 2.4 and $2.8 \mu \mathrm{g} \mathrm{m}^{-3}$, respectively). This is in line with a recent source apportionment study based on ACSM (Aerosol Chemical Speciation Monitor) measurements performed in Zürich for 13 months (February 2011-February 2012) which revealed substantial differences between the winter (February-March) and summer (June-August) $f_{44} / f_{43}$ space (organic mass fraction measured at mass to charge ratio 44 and 43 ), indicating that summer OOA (oxygenated organic aerosol) is strongly influenced by biogenic emission and winter OOA by biomass burning emission (Canonaco et al., 2015). Increased OA concentrations at Payerne in June 2006 with increased biogenic emissions were also found in other modelling studies. Bergström et al. (2012) used the VBS framework with different assumptions regarding aging processes and compared the model results for June 2006 with the AMS results at Payerne. In their study the total OA was found to be underpredicted with lower bias observed when aging processes were taken into account and biogenic emissions were increased by a factor of 3 . Even though their model differs from ours in various aspects (number of volatility bins, aging processes parameterization and input data) in two of their scenarios without aging of biogenic SOA, Bergström et al. (2012) predicted an average OA concentration ranging from 2.6 to $3.4 \mu \mathrm{g} \mathrm{m}^{-3}$, which is similar to our base case VBS_BC and VBS_BC_2xBVOC scenario $\left(2.4 \mu \mathrm{g} \mathrm{m}^{-3}\right.$ and $3.4 \mu \mathrm{g} \mathrm{m}^{-3}$, respectively; Table $\mathrm{S} 4$ ). 

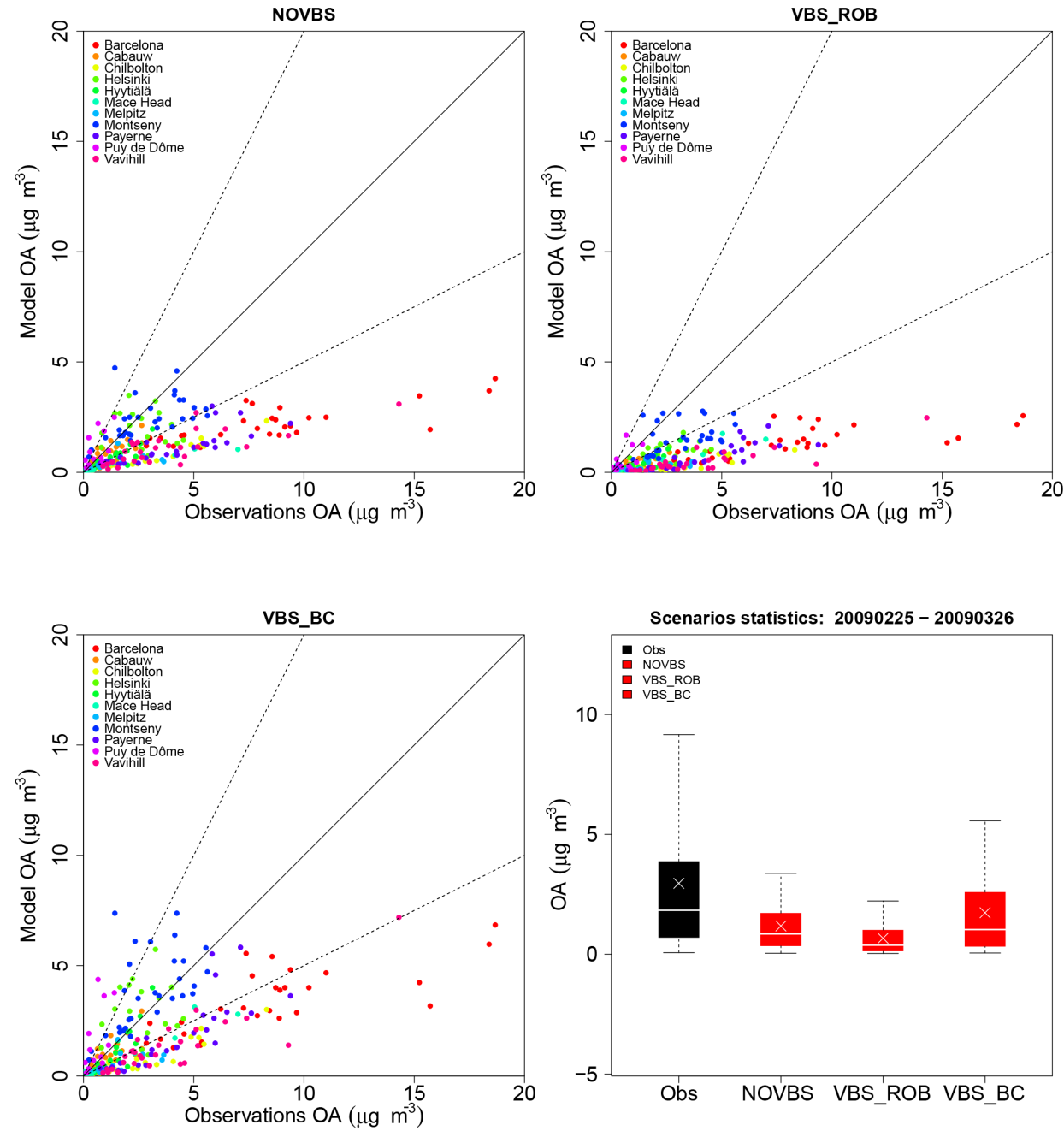

Figure 5. OA daily average scatter plots for NOVBS, VBS_ROB and VBS_BC scenarios for February-March 2009 for stations in Table 3. Solid lines indicate the $1: 1$ line. Dotted lines are the $1: 2$ and $2: 1$ lines. Box plots indicate medians, 5th, 25th, 75th and 95th quantiles for observations (black) and sensitivity tests (red). The crosses represent the arithmetic means. $R^{2}$ is 0.55 for NOVBS, 0.64 for VBS_ROB and 0.59 for VBS_BC (excluding the elevated sited of Puy de Dôme and Montseny).

\subsubsection{OA components in summer and winter}

Comparisons of the primary and secondary organic fractions at the rural site of Payerne during summer (June 2006) and winter (February-March 2009) periods are reported in Fig. 10. During the winter period the VBS scheme better reproduced the primary and secondary organic aerosol components compared to the NOVBS case. In particular, for the VBS_ROB base case, total OA concentrations were lower compared to the NOVBS case, consistent with the study of Woody et al. (2016) in which the same VBS scheme was applied to the US domain. The total OA concentrations in the base case (VBS_BC) and in the scenario with increased biomass burning emissions (VBS_BC_2xBBOA) were higher compared to NOVBS case, even though SOA and POA fractions were not correctly reproduced. Higher contribution from the primary fraction during winter periods was also predicted by the study of Koo et al. (2014) which deployed the same VBS scheme. Eventually, this might indicate that biomass burning precursors might be missing in this study or that the oxidation pathways of primary organic material need to be improved in the model (up to $86 \%$ of the reacted primary organic material is still allocated in the primary set as oxidation proceeds, directly increasing the POA fraction).

Different behaviour was observed for the summer period where the larger contribution of SOA to the total OA retrieved from measurements was also reproduced by the model, even though the total OA concentration was still underestimated. These results for summer are also in line with the study of Koo et al. (2014) for summer periods in the US domain using the same VBS scheme. 

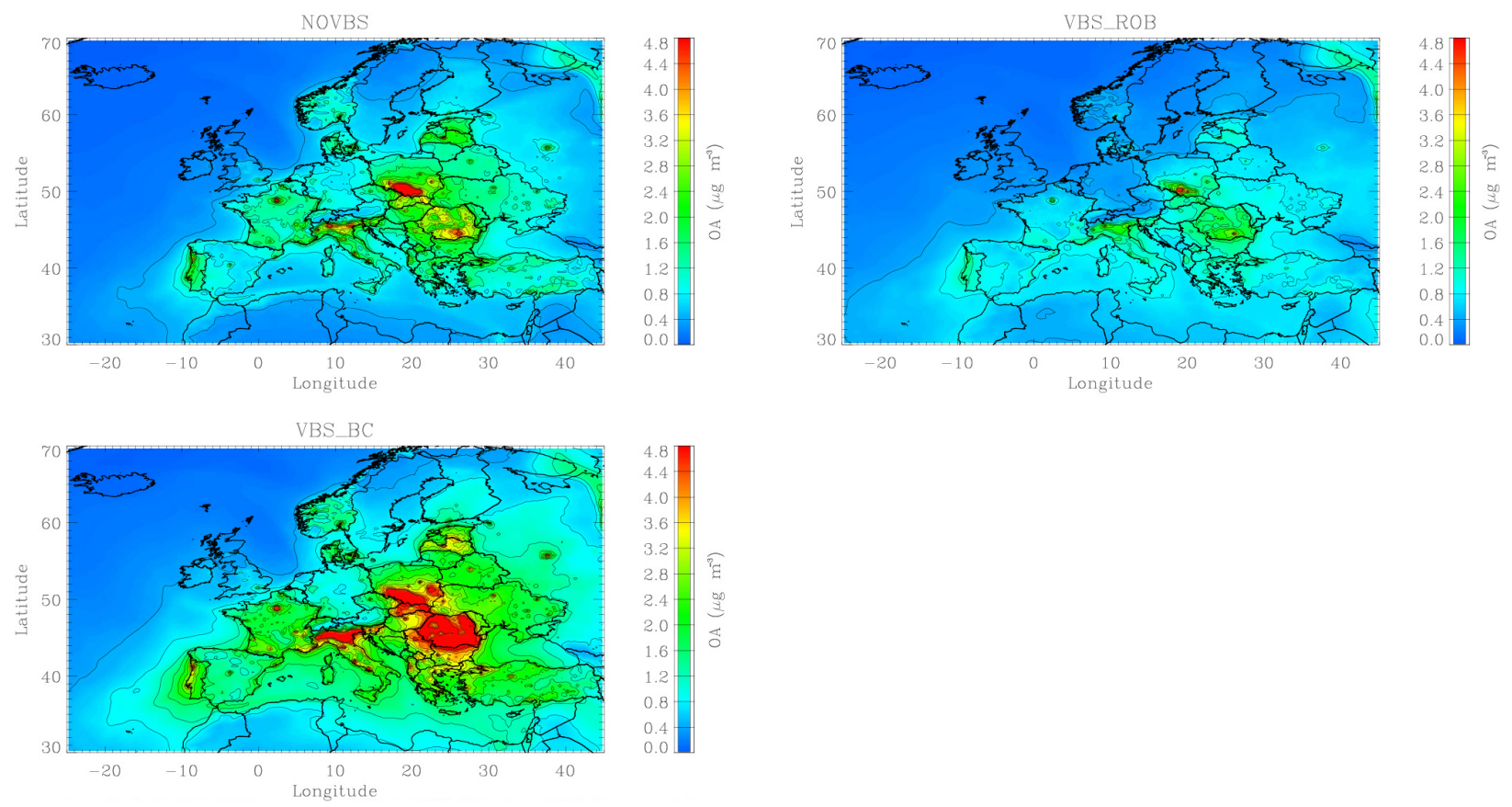

Figure 6. Predicted OA concentrations over Europe for the NOVBS, VBS_ROB and VBS_BC scenario in February-March 2009. Note that the colour scale was limited to a maximum of $4.8 \mu \mathrm{g} \mathrm{m}^{-3}$ to facilitate comparison of the panels.
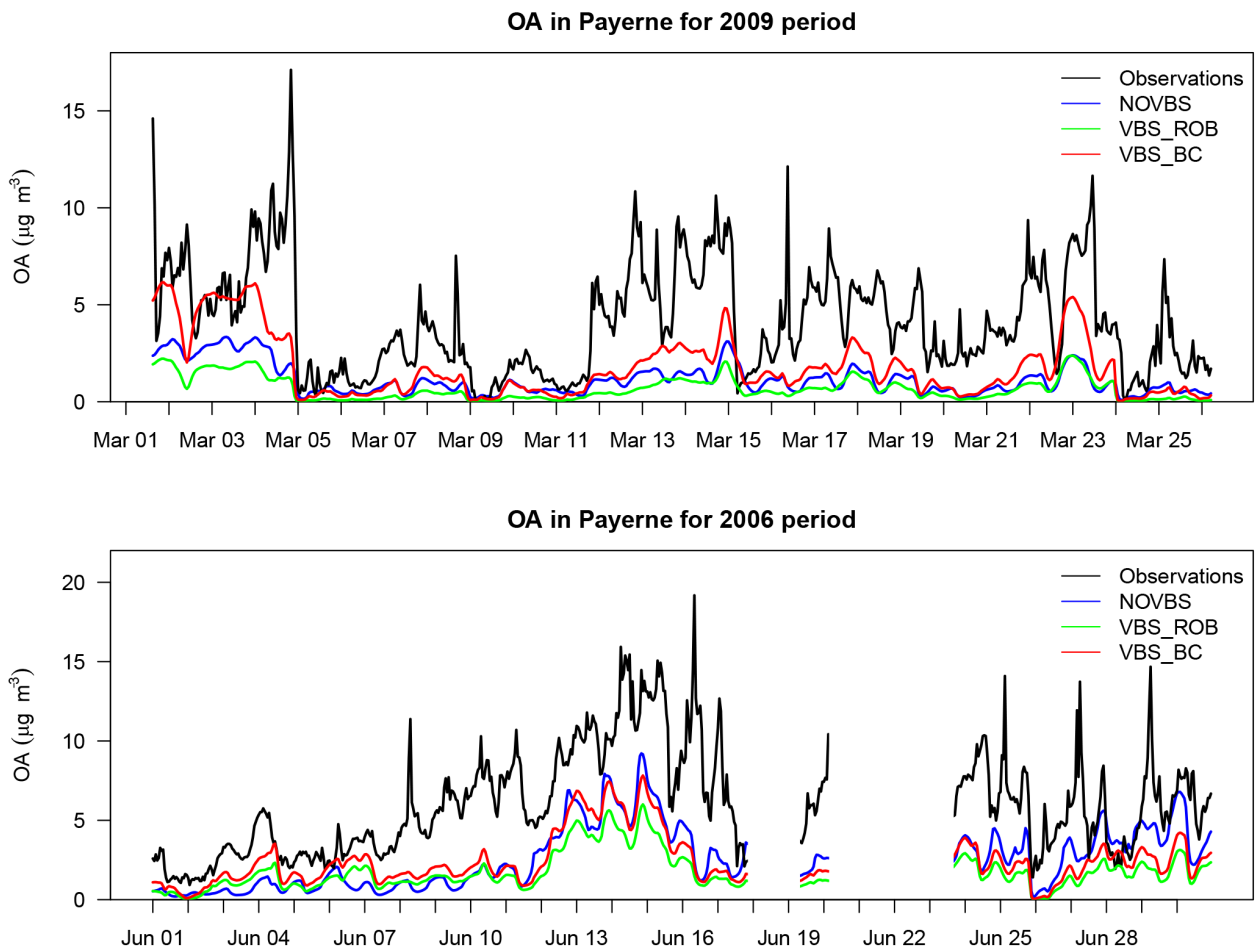

Figure 7. Predicted and observed total OA for scenarios NOVBS, VBS_ROB and VBS_BC in March 2009 (upper panel) and June 2006 (lower panel) at Payerne. 

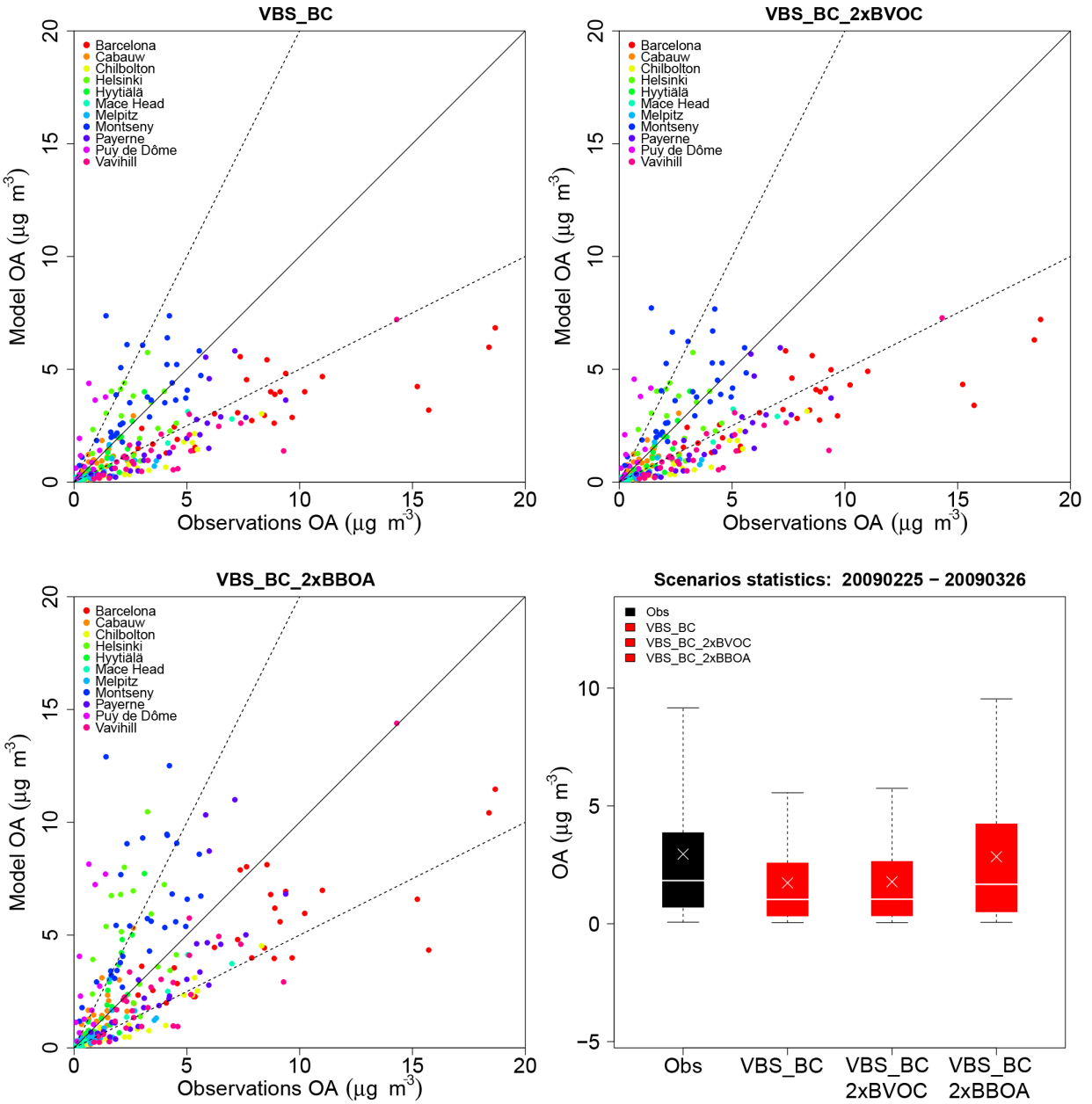

Figure 8. OA daily average scatter plots for VBS_BC, VBS_BC_2xBVOC and VBS_BC_2xBBOA scenarios for February-March 2009 for stations in Table 3. Solid lines indicate the 1:1 line. Dotted lines are the $1: 2$ and $2: 1$ lines. Box plots indicate medians, 5th, 25th, 75th and 95th quantiles for observations (black) and sensitivity tests (red). The crosses represent the arithmetic means.

\section{Conclusions}

A modelling study using the regional air quality model CAMx with a VBS scheme was performed for the first time in Europe within the EDIII model intercomparison exercise. An evaluation for the main gas phase species and $\mathrm{PM}_{2.5}$ for four different periods was performed using the European air quality database AirBase as well as AMS measurements. The period in February-March 2009 was further analysed in more detail using different assumptions regarding the volatility of emitted organic aerosol and precursor emissions. The main findings of this study are summarized below.

Although total $\mathrm{PM}_{2.5}$ mass concentrations and its variations were well reproduced by the model in all four periods, comparisons with AMS measurements for the FebruaryMarch 2009 period revealed that the good agreement between model and measurements was due, most of the time, to overestimation of the inorganic fraction, especially $\mathrm{NO}_{3}^{-}$, and underestimation of OA. Sensitivity tests with reduced
$\mathrm{NH}_{3}$ emissions generally reduced the positive bias in $\mathrm{NO}_{3}^{-}$, suggesting potential uncertainties in $\mathrm{NH}_{3}$ emissions and their seasonal variability.

In general, for all the four periods, the model underpredicted $\mathrm{NO}_{2}$ and $\mathrm{CO}$ concentrations. In contrast, $\mathrm{O}_{3}$ was found to be overpredicted likely because of insufficient $\mathrm{NO}_{x}$ to undergo titration during night-time chemistry or not wellcaptured vertical mixing processes and concentrations at the boundaries. $\mathrm{SO}_{2}$ was slightly overpredicted, presumably mainly because of uncertainties in high stack point source representation in the model or too low deposition processes.

Including evaporation and oxidation processes of primary organic particles with the volatility distribution proposed by Robinson et al. (2007) lowered the modelled OA mass both in winter and summer periods. However, the adjustment of the scheme by Robinson et al. (2007) suggested by Shrivastava et al. (2011) and Tsimpidi et al. (2010) brought model and observations into better agreement by reducing the negative bias for OA by about $29 \%$ (MFB) in winter. 


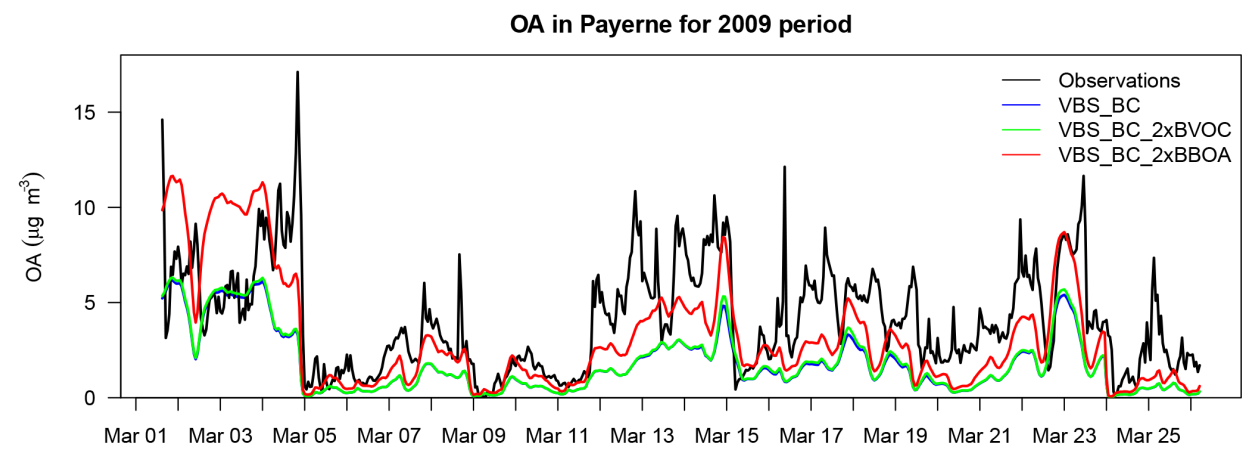

OA in Payerne for 2006 period

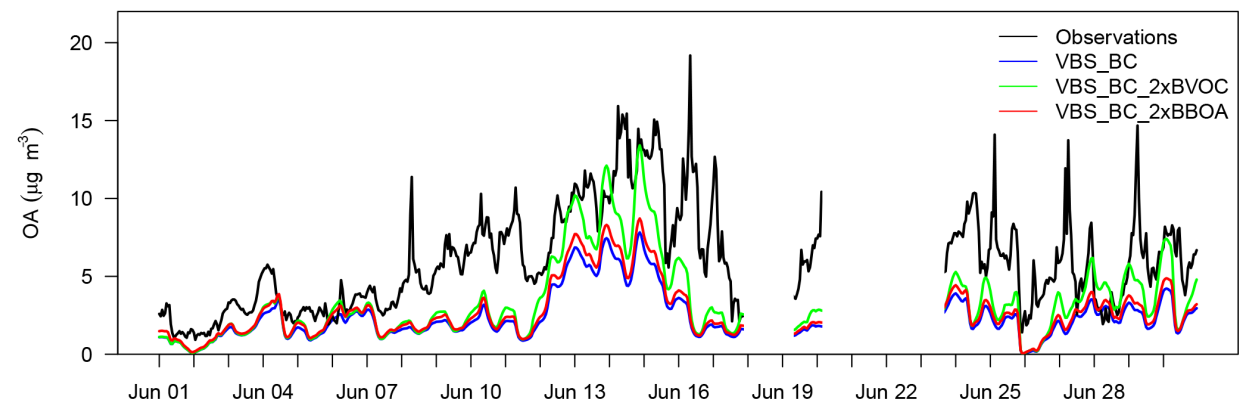

Figure 9. Predicted and observed total OA for scenarios VBS_BC, VBS_BC_2xBVOC and VBS_BC_2xBBOA in March 2009 (upper panel) and June 2006 (lower panel) at Payerne.

Sensitivity tests with increased BVOCs and BBOA-like emissions suggested that emissions from residential heating represent an important contributor to total OA during winter periods (February-March 2009). The model underpredicted the winter OA concentrations (MFB $-47 \%$ for base case VBS_BC) more than gas phase pollutants, e.g. $\mathrm{NO}_{2}$ (Table 2). Eventually, increasing BBOA-like emissions by a factor of 2 brought model and observation to a reasonably good agreement even though the model still underpredicted the OA fraction $(-12 \% \mathrm{MFB})$. This underlines the necessity to better constrain emission inventories with a focus on residential heating. Also, the implementation of the VBS scheme for domestic wood burning, which substantially influences both the primary and secondary organic aerosol, should be evaluated.

A summer period was simulated as well and results were compared at Payerne. In June 2006, the current VBS implementation could not explain the discrepancy between modelled and observed OA. During this period the difference between the model and measurements was likely related to BVOCs emissions which are uncertain and difficult to constrain with measurements. In this case the model was sensitive to an increase in biogenic emissions especially during periods with higher temperature and OA concentrations. The latter could confirm the importance of BVOC precursors in summer in Payerne and the way to correctly represent their evolution in the atmosphere.

\section{Data availability}

All data are available upon request from the corresponding authors. The CAMx model is available at http://www.camx. $\mathrm{com} /$.

The Supplement related to this article is available online at doi:10.5194/acp-16-10313-2016-supplement. 

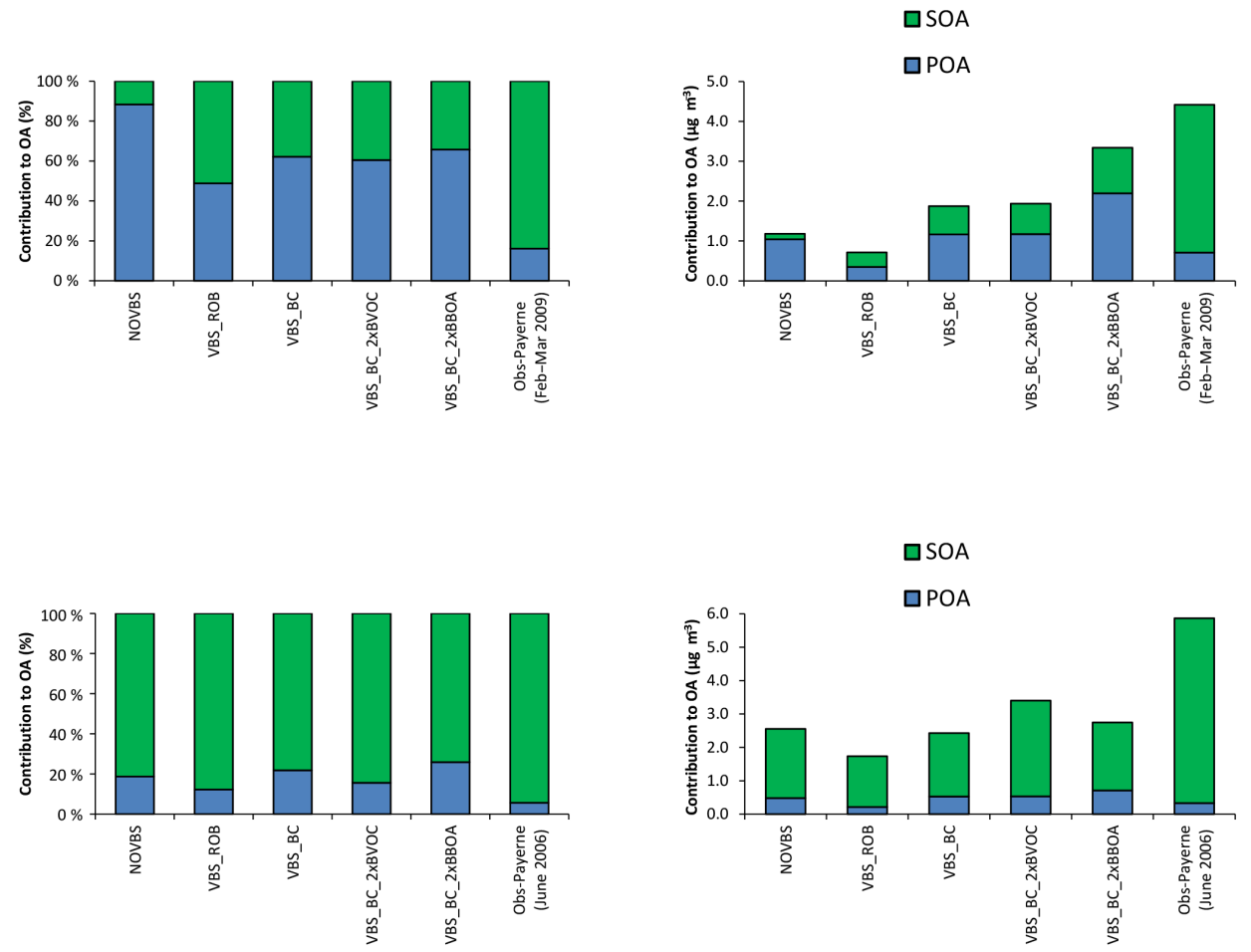

Figure 10. Relative (left) and absolute (right) contributions of predicted and measured POA and SOA fractions to the total OA mass at Payerne for February-March 2009 winter period (upper panel) and June 2006 (lower panel) and different model scenarios. NOVBS (traditional nonvolatile POA), VBS_ROB (Robinson et al., 2007), VBS_BC (Tsimpidi et al., 2010; Shrivastava et al., 2011), VBS_BC_2xBVOC (increased biogenic emissions relative to VBS_BC), VBS_BC_2xBBOA (increased biomass burning emissions relative to VBS_BC), ObsPayerne (AMS-PMF).

Acknowledgements. We thank the EURODELTA-III modelling community, especially INERIS for providing various model input data. We are grateful to ENVIRON for providing the CAMx-VBS code before its public release. Calculations of land-use data were performed with the Swiss National Supercomputing Centre (CSCS). We thank D. Oderbolz for developing the CAMxRunner framework to ensure reproducibility and data quality among the simulations and sensitivity tests. We thank M. Tinguely for the visualization software. We also thank G. Pirovano for helping with the pre-processing of AirBase data. This study was financially supported by the Swiss Federal Office of Environment (FOEN). J. L. Jimenez was supported by NSF AGS-1360834 and EPA STAR 83587701-0. We thank D. A. Day for analysis on the DAURE dataset, Erik Swietlicki for the Vavihill dataset, A. Kiendler-Scharr for Cabauw AMS data and Evelyn Freney for the Puy de Dôme dataset.

Edited by: J. Brandt

Reviewed by: two anonymous referees

\section{References}

Aksoyoglu, S., Keller, J., Barmpadimos, I., Oderbolz, D., Lanz, V. A., Prévôt, A. S. H., and Baltensperger, U.: Aerosol modelling in Europe with a focus on Switzerland during summer and winter episodes, Atmos. Chem. Phys., 11, 7355-7373, doi:10.5194/acp11-7355-2011, 2011.

Athanasopoulou, E., Vogel, H., Vogel, B., Tsimpidi, A. P., Pandis, S. N., Knote, C., and Fountoukis, C.: Modeling the meteorological and chemical effects of secondary organic aerosols during an EUCAARI campaign, Atmos. Chem. Phys., 13, 625-645, doi:10.5194/acp-13-625-2013, 2013.

Appel, K. W., Gilliam, R. C., Davis, N., Zubrow, A., and Howard, S. C.: Overview of the Atmospheric Model Evaluation Tool (AMET) v1.1 for evaluating meteorological and air quality models, Environ. Modell. Softw., 26, 434-443, 2011.

Benedetti, A., Morcrette, J.-J., Boucher, O., Dethof, A., Engelen, R. J., Fisher, M., Flentje, H., Huneeus, N., Jones, L., Kaiser, J. W., Kinne, S., Mangold, A., Razinger, M., Simmons, A. J., and Suttie, M.: Aerosol analysis and forecast in the European Centre for Medium-Range Weather Forecasts Integrated Forecast System: 2. data assimilation. J. Geophys. Res., 114, D13205, doi:10.1029/2008JD011115, 2009.

Bergström, R., Denier van der Gon, H. A. C., Prévôt, A. S. H., Yttri, K. E., and Simpson, D.: Modelling of organic aerosols over Europe (2002-2007) using a volatility basis set (VBS) framework: 
application of different assumptions regarding the formation of secondary organic aerosol, Atmos. Chem. Phys., 12, 8499-8527, doi:10.5194/acp-12-8499-2012, 2012.

Bessagnet, B., Colette, A., Meleux, F., Rouïl, L., Ung, A., Favez, O., Cuvelier, C., Thunis, P., Tsyro, S., Stern, R., Manders, A., Kranenburg, R., Aulinger, A., Bieser, J., Mircea, M., Briganti, G., Cappelletti, A., Calori, G., Finardi, S., Silibello, C., Ciarelli, G., Aksoyoglu, S., Prévôt, A., Pay, M.-T., Baldasano, J. M., García Vivanco, M., Garrido, J. L., Palomino, I., Martín, F., Pirovano, G., Roberts, P., Gonzalez, L., White, L., Menut, L., Dupont, J. C., Carnevale, C., and Pederzoli, A.: The EURODELTA III exercise "Model evaluation with observations issued from the 2009 EMEP intensive period and standard measurements in Feb/Mar 2009”, MSC-W Technical Report, 2014.

Bessagnet, B., Pirovano, G., Mircea, M., Cuvelier, C., Aulinger, A., Calori, G., Ciarelli, G., Manders, A., Stern, R., Tsyro, S., García Vivanco, M., Thunis, P., Pay, M.-T., Colette, A., Couvidat, F., Meleux, F., Rouïl, L., Ung, A., Aksoyoglu, S., Baldasano, J. M., Bieser, J., Briganti, G., Cappelletti, A., D’Isodoro, M., Finardi, S., Kranenburg, R., Silibello, C., Carnevale, C., Aas, W., Dupont, J.-C., Fagerli, H., Gonzalez, L., Menut, L., Prévôt, A. S. H., Roberts, P., and White, L.: Presentation of the EURODELTA III inter-comparison exercise - Evaluation of the chemistry transport models performance on criteria pollutants and joint analysis with meteorology, Atmos. Chem. Phys. Discuss., doi:10.5194/acp2015-736, in review, 2016.

Boylan, J. W. and Russell, A. G.: PM and light extinction model performance metrics, goals, and criteria for three-dimensional air quality models, Atmos. Environ., 40, 4946-4959, 2006.

Canonaco, F., Slowik, J. G., Baltensperger, U., and Prévôt, A. S. H.: Seasonal differences in oxygenated organic aerosol composition: implications for emissions sources and factor analysis, Atmos. Chem. Phys., 15, 6993-7002, doi:10.5194/acp-15-69932015, 2015.

Cappa, C. D. and Jimenez, J. L.: Quantitative estimates of the volatility of ambient organic aerosol, Atmos. Chem. Phys., 10, 5409-5424, doi:10.5194/acp-10-5409-2010, 2010.

Chang, J. S., Brost, R. A., Isaksen, I. S. A., Madronich, S., Middleton, P., Stockwell, W. R., and Walcek, C. J.: A three-dimensional eulerian acid deposition model: Physical concepts and formulation, J. Geophys. Res., 92, 14681-14700, 1987.

Ciarelli, G., El Haddad, I., Bruns, E., Aksoyoglu, S., Möhler, O., Baltensperger, U., and Prévôt, A. S. H.: Constraining a hybrid volatility basis set model for aging of wood burning emissions using smog chamber experiments, Geosci. Model Dev. Discuss., doi:10.5194/gmd-2016-163, in review, 2016.

Crippa, M., Canonaco, F., Lanz, V. A., Äijälä, M., Allan, J. D., Carbone, S., Capes, G., Ceburnis, D., Dall'Osto, M., Day, D. A., DeCarlo, P. F., Ehn, M., Eriksson, A., Freney, E., Hildebrandt Ruiz, L., Hillamo, R., Jimenez, J. L., Junninen, H., Kiendler-Scharr, A., Kortelainen, A.-M., Kulmala, M., Laaksonen, A., Mensah, A. A., Mohr, C., Nemitz, E., O’Dowd, C., Ovadnevaite, J., Pandis, S. N., Petäjä, T., Poulain, L., Saarikoski, S., Sellegri, K., Swietlicki, E., Tiitta, P., Worsnop, D. R., Baltensperger, U., and Prévôt, A. S. H.: Organic aerosol components derived from 25 AMS data sets across Europe using a consistent ME-2 based source apportionment approach, Atmos. Chem. Phys., 14, 61596176, doi:10.5194/acp-14-6159-2014, 2014.
Donahue, N., Robinson, A., Stanier, C., and Pandis, S.: Coupled partitioning, dilution, and chemical aging of semivolatile organics, Environ. Sci. Technol., 40, 2635-2643, 2006.

Donahue, N. M., Epstein, S. A., Pandis, S. N., and Robinson, A. L.: A two-dimensional volatility basis set: 1. organic-aerosol mixing thermodynamics, Atmos. Chem. Phys., 11, 3303-3318, doi:10.5194/acp-11-3303-2011, 2011.

Donahue, N. M., Henry, K. M., Mentel, T. F., Kiendler-Scharr, A., Spindler, C., Bohn, B., Brauers, T., Dorn, H. P., Fuchs, H., Tillmann, R., Wahner, A., Saathoff, H., Naumann, K. H., Mohler, O., Leisner, T., Muller, L., Reinnig, M. C., Hoffmann, T., Salo, K., Hallquist, M., Frosch, M., Bilde, M., Tritscher, T., Barmet, P., Praplan, A. P., DeCarlo, P. F., Dommen, J., Prevot, A. S. H., and Baltensperger, U.: Aging of biogenic secondary organic aerosol via gas-phase $\mathrm{OH}$ radical reactions, P. Natl. Acad. Sci. USA, 109, 13503-13508, doi:10.1073/pnas.1115186109, 2012a.

Donahue, N. M., Kroll, J. H., Pandis, S. N., and Robinson, A. L.: A two-dimensional volatility basis set - Part 2: Diagnostics of organic-aerosol evolution, Atmos. Chem. Phys., 12, 615-634, doi:10.5194/acp-12-615-2012, 2012 b.

Environ: User's Guide, Comprehensive Air Quality Model with Extensions (CAMx), Version 5.40, Environ International Corporation, California, 2011.

ETC/ACC, Improvement of classifications European monitoring stations for AirBase - A quality control, Technical Paper 2004/7.

Freney, E. J., Sellegri, K., Canonaco, F., Boulon, J., Hervo, M., Weigel, R., Pichon, J. M., Colomb, A., Prévôt, A. S. H., and Laj, P.: Seasonal variations in aerosol particle composition at the puy-de-Dôme research station in France, Atmos. Chem. Phys., 11, 13047-13059, doi:10.5194/acp-11-13047-2011, 2011.

Fountoukis, C., Racherla, P. N., Denier van der Gon, H. A. C., Polymeneas, P., Charalampidis, P. E., Pilinis, C., Wiedensohler, A., Dall'Osto, M., O’Dowd, C., and Pandis, S. N.: Evaluation of a three-dimensional chemical transport model (PMCAMx) in the European domain during the EUCAARI May 2008 campaign, Atmos. Chem. Phys., 11, 10331-10347, doi:10.5194/acp11-10331-2011, 2011.

Fountoukis, C., Megaritis, A. G., Skyllakou, K., Charalampidis, P. E., Pilinis, C., Denier van der Gon, H. A. C., Crippa, M., Canonaco, F., Mohr, C., Prévôt, A. S. H., Allan, J. D., Poulain, L., Petäjä, T., Tiitta, P., Carbone, S., Kiendler-Scharr, A., Nemitz, E., O'Dowd, C., Swietlicki, E., and Pandis, S. N.: Organic aerosol concentration and composition over Europe: insights from comparison of regional model predictions with aerosol mass spectrometer factor analysis, Atmos. Chem. Phys., 14, 9061-9076, doi:10.5194/acp-14-9061-2014, 2014.

Guenther, A. B., Jiang, X., Heald, C. L., Sakulyanontvittaya, T., Duhl, T., Emmons, L. K., and Wang, X.: The Model of Emissions of Gases and Aerosols from Nature version 2.1 (MEGAN2.1): an extended and updated framework for modeling biogenic emissions, Geosci. Model Dev., 5, 1471-1492, doi:10.5194/gmd-51471-2012, 2012.

Hallquist, M., Wenger, J. C., Baltensperger, U., Rudich, Y., Simpson, D., Claeys, M., Dommen, J., Donahue, N. M., George, C., Goldstein, A. H., Hamilton, J. F., Herrmann, H., Hoffmann, T., Iinuma, Y., Jang, M., Jenkin, M. E., Jimenez, J. L., Kiendler-Scharr, A., Maenhaut, W., McFiggans, G., Mentel, Th. F., Monod, A., Prévôt, A. S. H., Seinfeld, J. H., Surratt, J. D., Szmigielski, R., and Wildt, J.: The formation, properties and im- 
pact of secondary organic aerosol: current and emerging issues, Atmos. Chem. Phys., 9, 5155-5236, doi:10.5194/acp-9-51552009, 2009.

Hodzic, A., Jimenez, J. L., Madronich, S., Canagaratna, M. R., DeCarlo, P. F., Kleinman, L., and Fast, J.: Modeling organic aerosols in a megacity: potential contribution of semi-volatile and intermediate volatility primary organic compounds to secondary organic aerosol formation, Atmos. Chem. Phys., 10, 5491-5514, doi:10.5194/acp-10-5491-2010, 2010.

Inness, A., Baier, F., Benedetti, A., Bouarar, I., Chabrillat, S., Clark, H., Clerbaux, C., Coheur, P., Engelen, R. J., Errera, Q., Flemming, J., George, M., Granier, C., Hadji-Lazaro, J., Huijnen, V., Hurtmans, D., Jones, L., Kaiser, J. W., Kapsomenakis, J., Lefever, K., Leitão, J., Razinger, M., Richter, A., Schultz, M. G., Simmons, A. J., Suttie, M., Stein, O., Thépaut, J.-N., Thouret, V., Vrekoussis, M., Zerefos, C., and the MACC team: The MACC reanalysis: an $8 \mathrm{yr}$ data set of atmospheric composition, Atmos. Chem. Phys., 13, 4073-4109, doi:10.5194/acp-13-4073-2013, 2013

Jo, D. S., Park, R. J., Kim, M. J., and Spracklen, D. V.: Effects of chemical aging on global secondary organic aerosol using the volatility basis set approach, Atmos. Environ., 81, 230-244, doi:10.1016/j.atmosenv.2013.08.055, 2013.

Knote, C., Brunner, D., Vogel, H., Allan, J., Asmi, A., Äijälä, M., Carbone, S., van der Gon, H. D., Jimenez, J. L., KiendlerScharr, A., Mohr, C., Poulain, L., Prévôt, A. S. H., Swietlicki, E., and Vogel, B.: Towards an online-coupled chemistry-climate model: evaluation of trace gases and aerosols in COSMO-ART, Geosci. Model Dev., 4, 1077-1102, doi:10.5194/gmd-4-10772011, 2011.

Koo, B., Knipping, E., and Yarwood, G.: 1.5-Dimensional volatility basis set approach for modeling organic aerosol in CAMx and CMAQ, Atmos Environ., 95, 158-164, 2014.

Kuenen, J. J. P., Denier van der Gon, H. A. C., Visschedijk, A., Van der Brugh, H., and Van Gijlswijk, R.: MACC European emission inventory for the years 2003-2007, TNO report TNO- 060-UT2011-00588, TNO, Utrecht, 2011.

Kulmala, M., Asmi, A., Lappalainen, H. K., Carslaw, K. S., Pöschl, U., Baltensperger, U., Hov, Ø., Brenquier, J.-L., Pandis, S. N., Facchini, M. C., Hansson, H.-C., Wiedensohler, A., and O'Dowd, C. D.: Introduction: European Integrated Project on Aerosol Cloud Climate and Air Quality interactions (EUCAARI) - integrating aerosol research from nano to global scales, Atmos. Chem. Phys., 9, 2825-2841, doi:10.5194/acp-9-2825-2009, 2009.

Kulmala, M., Asmi, A., Lappalainen, H. K., Baltensperger, U., Brenguier, J.-L., Facchini, M. C., Hansson, H.-C., Hov, Ø., O'Dowd, C. D., Pöschl, U., Wiedensohler, A., Boers, R., Boucher, O., de Leeuw, G., Denier van der Gon, H. A. C., Feichter, J., Krejci, R., Laj, P., Lihavainen, H., Lohmann, U., McFiggans, G., Mentel, T., Pilinis, C., Riipinen, I., Schulz, M., Stohl, A., Swietlicki, E., Vignati, E., Alves, C., Amann, M., Ammann, M., Arabas, S., Artaxo, P., Baars, H., Beddows, D. C. S., Bergström, R., Beukes, J. P., Bilde, M., Burkhart, J. F., Canonaco, F., Clegg, S. L., Coe, H., Crumeyrolle, S., D’Anna, B., Decesari, S., Gilardoni, S., Fischer, M., Fjaeraa, A. M., Fountoukis, C., George, C., Gomes, L., Halloran, P., Hamburger, T., Harrison, R. M., Herrmann, H., Hoffmann, T., Hoose, C., Hu, M., Hyvärinen, A., Hõrrak, U., Iinuma, Y., Iversen, T., Josipovic,
M., Kanakidou, M., Kiendler-Scharr, A., Kirkevåg, A., Kiss, G., Klimont, Z., Kolmonen, P., Komppula, M., Kristjánsson, J.-E., Laakso, L., Laaksonen, A., Labonnote, L., Lanz, V. A., Lehtinen, K. E. J., Rizzo, L. V., Makkonen, R., Manninen, H. E., McMeeking, G., Merikanto, J., Minikin, A., Mirme, S., Morgan, W. T., Nemitz, E., O’Donnell, D., Panwar, T. S., Pawlowska, H., Petzold, A., Pienaar, J. J., Pio, C., Plass-Duelmer, C., Prévôt, A. S. H., Pryor, S., Reddington, C. L., Roberts, G., Rosenfeld, D., Schwarz, J., Seland, Ø., Sellegri, K., Shen, X. J., Shiraiwa, M., Siebert, H., Sierau, B., Simpson, D., Sun, J. Y., Topping, D., Tunved, P., Vaattovaara, P., Vakkari, V., Veefkind, J. P., Visschedijk, A., Vuollekoski, H., Vuolo, R., Wehner, B., Wildt, J., Woodward, S., Worsnop, D. R., van Zadelhoff, G.-J., Zardini, A. A., Zhang, K., van Zyl, P. G., Kerminen, V.-M., S Carslaw, K., and Pandis, S. N.: General overview: European Integrated project on Aerosol Cloud Climate and Air Quality interactions (EUCAARI) - integrating aerosol research from nano to global scales, Atmos. Chem. Phys., 11, 13061-13143, doi:10.5194/acp11-13061-2011, 2011.

Lane, T. E., Donahue, N. M., and Pandis, S. N.: Simulating secondary organic aerosol formation using the volatility basis-set approach in a chemical transport model, Atmos. Environ., 42, 7439-7451, doi:10.1016/j.atmosenv.2008.06.026, 2008.

Langmann, B., Sellegri, K., and Freney, E.: Secondary organic aerosol formation during June 2010 in Central Europe: measurements and modelling studies with a mixed thermodynamic-kinetic approach, Atmos. Chem. Phys., 14, 3831-3842, doi:10.5194/acp-14-3831-2014, 2014.

Li, Y. P., Elbern, H., Lu, K. D., Friese, E., Kiendler-Scharr, A., Mentel, Th. F., Wang, X. S., Wahner, A., and Zhang, Y. H.: Updated aerosol module and its application to simulate secondary organic aerosols during IMPACT campaign May 2008, Atmos. Chem. Phys., 13, 6289-6304, doi:10.5194/acp-13-6289-2013, 2013.

Mensah, A. A., Holzinger, R., Otjes, R., Trimborn, A., Mentel, Th. F., ten Brink, H., Henzing, B., and Kiendler-Scharr, A.: Aerosol chemical composition at Cabauw, The Netherlands as observed in two intensive periods in May 2008 and March 2009, Atmos. Chem. Phys., 12, 4723-4742, doi:10.5194/acp-12-4723-2012, 2012.

Murphy, B. N. and Pandis, S. N.: Simulating the formation of semivolatile primary and secondary organic aerosol in a regional chemical transport model, Environ. Sci. Technol., 43, 47224728, 2009.

Murphy, B. N., Donahue, N. M., Fountoukis, C., Dall'Osto, M., O'Dowd, C., Kiendler-Scharr, A., and Pandis, S. N.: Functionalization and fragmentation during ambient organic aerosol aging: application of the 2-D volatility basis set to field studies, Atmos. Chem. Phys., 12, 10797-10816, doi:10.5194/acp-1210797-2012, 2012.

NASA/GSFC: Total ozone mapping spectrometer, available at: http: //ozoneaq.gsfc.nasa.gov (last access: 4 August 2016), 2005.

Nenes, A., Pandis, S. N., and Pilinis, C.: ISORROPIA: A new thermodynamic equilibrium model for multiphase multicomponent inorganic aerosols, Aquat. Geochem., 4, 123-152, 1998.

O'Brien, J. J.: A note on the vertical structure of the eddy exchange coefficient in the planetary boundary layer, J. Atmos. Sci., 27, 1213-1215, 1970. 
Pandolfi, M., Querol, X., Alastuey, A., Jimenez, J. L., Jorba, O., Day, D., Ortega, A., Cubison, M. J., Comerón, A., Sicard, M., Mohr, C., Prévôt, A. S. H., Minguillón, M. C., Pey, J., Baldasano, J. M., Burkhart, J. F., Seco, R., Peñuelas, J., Van Drooge, B. L., Artiñano, B., Di Marco, C., Nemitz, E., Schallhart, S., Metzger, A., Hansel, A., Lorente, J., Ng, S., Jayne J., and Szidat, S.: Effects of sources and meteorology on particulate matter in the Western Mediterranean Basin: an overview of the DAURE campaign, J. Geophys. Res. Atmos., 119, 4978-5010, doi:10.1002/2013JD021079, 2014.

Passant, N. R.: Speciation of UK emissions of non-methane volatile organic compounds, AEA Technology, Culham, 289, 2002.

Robinson, A. L., Donahue, N. M., Shrivastava, M. K., Weitkamp, E. A., Sage, A. M., Grieshop, A. P., Lane, T. E., Pierce, J. R., and Pandis, S. N.: Rethinking organic aerosols: semivolatile emissions and photochemical aging, Science, 315, 1259-1262, doi:10.1126/science.1133061, 2007.

Shrivastava, M., Fast, J., Easter, R., Gustafson Jr., W. I., Zaveri, R. A., Jimenez, J. L., Saide, P., and Hodzic, A.: Modeling organic aerosols in a megacity: comparison of simple and complex representations of the volatility basis set approach, Atmos. Chem. Phys., 11, 6639-6662, doi:10.5194/acp-11-6639-2011, 2011.

Solazzo, E., Bianconi, R., Pirovano, G., Matthias, V., Vautard, R., Moran, M. D., Appel, K. W., Bessagnet, B., Brandt, J., Christensen, J. H., Chemel, C., Coll, I., Ferreira, J., Forkel, R., Francis, X. V., Grell, G., Grossi, P., Hansen, A. B., Miranda, A. I., Nopmongcol, U., Prank, M., Sartelet, K. N., Schaap, M., Silver, J. D., Sokhi, R. S., Vira, J., Werhahn, J., Wolke, R., Yarwood, G., Zhang, J., Rao, S. T., and Galmarini, S.: Operational model evaluation for particulate matter in Europe and North America in the context of AQMEII, Atmos. Environ., 53, 75-92, doi:10.1016/j.atmosenv.2012.02.045, 2012.

Starcrest Consulting Group, LLC, Starcrest Consulting Group, LLC.: Port-Wide Baseline Air Emissions Inventory. Prepared for the Port of Los Angeles, California, 2004.

Steinbacher, M., Zellweger, C., Schwarzenbach, B., Bugmann, S., Buchmann, B., Ordóñez, C., Prevot, A. S. H., and Hueglin, C.: Nitrogen oxides measurements at rural sites in Switzerland: bias of conventional measurement techniques, J. Geophys. Res., 112, D11307, doi:10.1029/2006JD007971, 2007.

Strader, R., Lurmann, F., and Pandis, S. N.: Evaluation of secondary organic aerosol formation in winter, Atmos. Environ., 33, 48494863, 1999.

Tsigaridis, K., Daskalakis, N., Kanakidou, M., Adams, P. J., Artaxo, P., Bahadur, R., Balkanski, Y., Bauer, S. E., Bellouin, N., Benedetti, A., Bergman, T., Berntsen, T. K., Beukes, J. P., Bian, H., Carslaw, K. S., Chin, M., Curci, G., Diehl, T., Easter, R. C., Ghan, S. J., Gong, S. L., Hodzic, A., Hoyle, C. R., Iversen, T., Jathar, S., Jimenez, J. L., Kaiser, J. W., Kirkevåg, A., Koch, D., Kokkola, H., Lee, Y. H., Lin, G., Liu, X., Luo, G., Ma, X., Mann, G. W., Mihalopoulos, N., Morcrette, J.-J., Müller, J.-F., Myhre, G., Myriokefalitakis, S., Ng, N. L., O’Donnell, D., Penner, J. E., Pozzoli, L., Pringle, K. J., Russell, L. M., Schulz, M., Sciare, J., Seland, Ø., Shindell, D. T., Sillman, S., Skeie, R. B., Spracklen, D., Stavrakou, T., Steenrod, S. D., Takemura, T., Tiitta, P., Tilmes, S., Tost, H., van Noije, T., van Zyl, P. G., von Salzen, K., Yu, F., Wang, Z., Wang, Z., Zaveri, R. A., Zhang, H., Zhang, K., Zhang, Q., and Zhang, X.: The AeroCom evaluation and intercomparison of organic aerosol in global mod- els, Atmos. Chem. Phys., 14, 10845-10895, doi:10.5194/acp-1410845-2014, 2014.

Tsimpidi, A. P., Karydis, V. A., Zavala, M., Lei, W., Molina, L., Ulbrich, I. M., Jimenez, J. L., and Pandis, S. N.: Evaluation of the volatility basis-set approach for the simulation of organic aerosol formation in the Mexico City metropolitan area, Atmos. Chem. Phys., 10, 525-546, doi:10.5194/acp-10-525-2010, 2010.

Tørseth, K., Aas, W., Breivik, K., Fjæraa, A. M., Fiebig, M., Hjellbrekke, A. G., Lund Myhre, C., Solberg, S., and Yttri, K. E.: Introduction to the European Monitoring and Evaluation Programme (EMEP) and observed atmospheric composition change during 1972-2009, Atmos. Chem. Phys., 12, 5447-5481, doi:10.5194/acp-12-5447-2012, 2012.

Vaughan, A. R., Lee, J. D., Misztal, P. K., Metzger, S., Shaw, M. D., Lewis, A. C., Purvis, R. M., Carslaw, D. C., Goldstein, A. H., Hewitt, C. N., Davison, B., Beevers, S. D., and Karl, T. G.: Spatially resolved flux measurements of $\mathrm{NO}_{x}$ from London suggest significantly higher emissions than predicted by inventories, Faraday Discuss., 112, D11307, doi:10.1039/C5FD00170F, 2016.

Vestreng, V., Myhre, G., Fagerli, H., Reis, S., and Tarrasón, L.: Twenty-five years of continuous sulphur dioxide emission reduction in Europe, Atmos. Chem. Phys., 7, 3663-3681, doi:10.5194/acp-7-3663-2007, 2007.

Villena, G., Bejan, I., Kurtenbach, R., Wiesen, P., and Kleffmann, J.: Interferences of commercial $\mathrm{NO}_{2}$ instruments in the urban atmosphere and in a smog chamber, Atmos. Meas. Tech., 5, 149-159, doi:10.5194/amt-5-149-2012, 2012.

WHO: Burden of disease from Ambient Air Pollution for 2012 - Summary of Results, available at: http://www.who.int/phe/health_topics/outdoorair/databases/ AAP_BoD_results_March2014.pdf, 2014.

Woody, M. C., Baker, K. R., Hayes, P. L., Jimenez, J. L., Koo, B., and Pye, H. O. T.: Understanding sources of organic aerosol during CalNex-2010 using the CMAQ-VBS, Atmos. Chem. Phys., 16, 4081-4100, doi:10.5194/acp-16-4081-2016, 2016.

Yarwood, G., Rao, S., Yocke, M., and Whitten, G. Z.: Updates to the Carbon Bond Chemical Mechanism: CB05 Yocke \& Company, Novato, CA 94945RT-04-00675, 2005.

Zhang, L., Brook, J. R., and Vet, R.: A revised parameterization for gaseous dry deposition in air-quality models, Atmos. Chem. Phys., 3, 2067-2082, doi:10.5194/acp-3-2067-2003, 2003.

Zhang, Q. J., Beekmann, M., Drewnick, F., Freutel, F., Schneider, J., Crippa, M., Prevot, A. S. H., Baltensperger, U., Poulain, L., Wiedensohler, A., Sciare, J., Gros, V., Borbon, A., Colomb, A., Michoud, V., Doussin, J.-F., Denier van der Gon, H. A. C., Haeffelin, M., Dupont, J.-C., Siour, G., Petetin, H., Bessagnet, B., Pandis, S. N., Hodzic, A., Sanchez, O., Honoré, C., and Perrussel, O.: Formation of organic aerosol in the Paris region during the MEGAPOLI summer campaign: evaluation of the volatilitybasis-set approach within the CHIMERE model, Atmos. Chem. Phys., 13, 5767-5790, doi:10.5194/acp-13-5767-2013, 2013. 